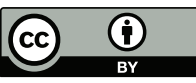

DOI 10.4467/12332135KRA.20.004.13552

\title{
Kamila Follprecht
}

ORCID: 0000-0002-0776-7576

Archiwum Narodowe w Krakowie

\section{Andrzej Gaczoł}

ORCID: 0000-0002-0806-8902

Konserwator zabytków, Kraków

\section{Tadeusz Bierczyński - Pamiętnik Legionisty 1914-1915}

\section{Tadeusz Bierczyński - Journal of a Legionary 1914-1915}

SŁOWA KLUCZOWE: Tadeusz Bierczyński, Legiony, 2. Pułk Piechoty, I wojna światowa KEY WORDS: Tadeusz Bierczyński, Legions, $2^{\text {nd }}$ Infantry Regiment, World War I

\begin{abstract}
ABSTRAKT: Tadeusz Bierczyński (1891-1970), absolwent prawa UJ, dowodził oddziałem „Sokoła”, który wyruszył z Wieliczki 25 sierpnia 1914 r. do tworzących się w Krakowie Legionów. Służył w 2. Pułku Piechoty, uczestniczył w zimowej ofensywie II Brygady, brał udział w najcięższych bitwach na Bukowinie: pod Kirlibabą (17-21 stycznia 1915 r.) oraz Korolówką (6-7 marca 1915 r.). Podczas walk zapisywał wydarzenia z życia legionisty, jednak zachowały się tylko fragmenty maszynopisu tekstu dziennika, obejmujące wydarzenia od 25 sierpnia do 21 października 1914 r., następnie od 10 stycznia do 9 marca 1915 r. oraz od 11 do 31 maja 1915 r. Zawierają interesujące informacje nie tylko o przebiegu działań wojennych, ale o życiu codziennym legionistów, spojrzenie na organizację działań wojskowych, wiadomości o legionistach czy opisy miejsc, w których oddziały stacjonowały.
\end{abstract}

\begin{abstract}
Tadeusz Bierczyński (1891-1970), a graduate of law at Jagiellonian University, led the "Falcon" unit, which set off from Wieliczka on 25 August 1914 to join the Legions forming in Krakow. He served in the $2^{\text {nd }}$ Infantry Regiment, participating in the winter offensive of the II Brigade and the tough battles in Carlibaba (17-21 January 1915) and Korolówka (6-7 March 1915). During the fighting, he described the events from the life of a legionary, however, only fragments of his typed journal remain, covering events from 25 August until 21 October 1914, then from 10 January until 9 March 1915 and from 11 to 31 May 1915. They contain interesting information not only about the military activities,
\end{abstract}


but also about the daily life of the legionaries, the view of the organisation of military actions, news about legionaries as well as descriptions of places in which the divisions were stationed.

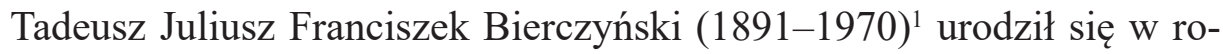
dzinie mieszkających w mieście Podgórzu (od 1915 r. część Krakowa) nauczycieli Stanisława Bierczyńskiego (1865-1897)² i Wandy z domu Heyda (1864-1947) ${ }^{3}$. Ze strony ojca był potomkiem Ludwika Bierczyńskiego (1834 - po 1905), kościelnego w parafii św. Floriana w Krakowie ${ }^{4}$, a ze strony matki - starszego sztygara w Kopalni Soli w Wieliczce i radnego

${ }^{1}$ Życiorys Tadeusza Bierczyńskiego zob. Andrzej Gaczoł, Tadeusz Bierczyński (1891-1970). Legionista, adwokat, poset na Sejm II RP - represjonowany przez reżim stalinowski, „Sowiniec” 2007, nr 31, s. 51-60. Informacje o rodzinie zostały uzupełnione o aktualne ustalenia i publikacje.

${ }^{2}$ Był uczniem c.k. Gimnazjum św. Jacka w Krakowie, ukończył c.k. Seminarium Nauczycielskie Męskie w Krakowie, pracował jako nauczyciel w: 8-klasowej szkole wydziałowej w Wieliczce (1885-1887), szkole filialnej w Gruszowie (1888-1889), 4-klasowej szkole etatowej męskiej w Podgórzu (1890-1893), 3-klasowej etatowej szkole mieszanej w Skawinie (1894, kierownik), 6-klasowej szkole etatowej męskiej w Wieliczce (1895), 5-klasowej etatowej szkole męskiej w Oświęcimiu (1896), 5-klasowej etatowej szkole męskiej w Mielcu (1897), ANK, Gimnazjum i Liceum św. Jacka w Krakowie, sygn. 29/487/15, 16; ANK, C.K. Seminarium Nauczycielskie Męskie w Krakowie, sygn. 29/489/79, 80; Szematyzm królestwa Galicyi i Lodomeryi z Wielkim Księstwem Krakowskiem na rok 1886-1914.

${ }^{3}$ Pracowała jako nauczycielka w: 5-klasowej etatowej szkole żeńskiej w Wieliczce (1888-1890), 5-klasowej etatowej szkole żeńskiej w Mielcu (1898-1902), 1-klasowej etatowej szkole żeńskiej w Śledziejowicach (1903), 3-klasowej wydziałowej szkole żeńskiej połączonej z 4-klasową szkołą pospolitą w Wieliczce (1904-1910), 4-klasowej etatowej szkole żeńskiej w Wieliczce (1911), 1-klasowej etatowej szkole żeńskiej w Czarnochowicach (1912-1913), Szematyzm królestwa Galicyi i Lodomeryi z Wielkim Księstwem Krakowskiem na rok 1889-1914.

${ }^{4}$ Był synem Franciszka, szynkarza we wsi Ujazd, ANK, Akta stanu cywilnego Parafii Rzymskokatolickiej w Bolechowicach, sygn. 29/337/59, nr 59; ANK, Spis ludności miasta Krakowa z r. 1870, sygn. 29/86/8, s. 233-234; ANK, Spis ludności miasta Krakowa z r. 1880, sygn. 29/87/14, s. 305-306; Księga adresowa król. stot. miasta Krakowa i król. woln. Miasta Podgórza Rok 1905, Spis alfabetyczny mieszkańców miasta Krakowa z podaniem stanowiska, tytułu i mieszkania, s. 15. 
miejskiego Juliusza Heydy vel Hejdy (1824-1901). Miał dwie siostry, również nauczycielki: Zofię (1892-1935)5 oraz Helenę (1894-1975).

Stanisław Bierczyński jako nauczyciel został przeniesiony do Mielca, gdzie zmarł w 1897 r. po niespełna rocznym pobycie. Wdowa z trójką małych dzieci powróciła w1903 r. do domu rodzinnego w Wieliczce, gdzie Tadeusz Bierczyński ukończył Pospolitą Szkołę Męską, a następnie w 1910 r. C.K. Wyższe Gimnazjum w Podgórzu' ${ }^{6}$ W latach 1910-1914 studiował na Wydziale Prawa Uniwersytetu Jagiellońskiego w Krakowie - studia ukończył w 1914 r. (absolutorium uzyskał dopiero 22 sierpnia 1918 r.). Od grudnia 1912 r. był członkiem wspierającym Związku Strzeleckiego w Wieliczce (pseudonim: Heród). W 1913 r. przeniósł się do Stałej Drużyny Polowej Towarzystwa Gimnastycznego „Sokół”, która rozpoczęła działalność pod komendą Stanisława Chudoby, przy czynnym wsparciu ówczesnego burmistrza miasta Franciszka Aywasa (1862-1940). Po przeszkoleniu został drużynowym dwóch drużyn skautowych: „Zawiszy Czarnego” i „Henryka Dąbrowskiego".

T. Bierczyński dowodził 65-osobowym oddziałem wielickiego „Sokoła", który wyruszył z Wieliczki do Krakowa 25 sierpnia 1914 r. Ochotników wcielono do II Brygady Legionów Polskich - T. Bierczyński w stopniu chorążego służył w II batalionie 2. Pułku Piechoty (w 1914 r. w 8. kompanii, na początku 1915 r. w 7. kompanii) ${ }^{7}$, dowodzonym przez pułkownika Zygmunta Zielińskiego. Uczestniczył w zimowej ofensywie II Brygady, dowodząc sekcją, a następnie III plutonem w 8. kompanii w II batalionie 2. Pułku Piechoty w dwu najcięższych bitwach na Bukowinie - pod Kirlibabą (17-21 stycznia 1915 r.) oraz Korolówką (6-7 marca 1915 r.). Po 17 marca 1915 r.,

${ }^{5}$ W latach 30. XX w. kierowała Żeńską Szkołą Powszechną im. Królowej Jadwigi w Wieliczce.

${ }^{6}$ W Podgórzu mieszkał z rodziną i pracował od 1892 r. brat ojca - Żegota (Tomasz Ignacy) Bierczyński (2 stycznia 1870 r. - 27 kwietnia 1935 r.), w 1. 1894-1915 jako koncepista podgórskiego Magistratu, od 1915 r. w krakowskim Magistracie jako komisarz, od $1921 \mathrm{r}$. naczelnik kancelarii w Wydziale Wojskowym, od 1928 r. z tytułem sekretarza Magistratu, od 1931 r. z tytułem radcy administracyjnego Magistratu, ANK, Akta miasta Krakowa, Akta osobowe pracowników, sygn. 29/33/6.11/Osob.1723.

${ }^{7}$ Na podstawie: Obsada personalna 2. pułku dnia 28.IX.1914; Obsada personalna 2. pukku w czasie od 6 do 28.X.1914; Obsada personalna 2. pułku w dniu boju pod Mołotkowem - 29.X.1914; Obsada personalna 2. pułku od 20.II. do 17.III.1915, Tadeusz Malinowski, Mieczysław Szumański, 2. Pułk Piechoty Legionów Polskich. I Karpaty. Kronika działań bojowych, Warszawa 1939, s. 61, 167, 212, 676. 
czyli po odejściu płk. Zygmunta Zielińskiego z frontu, T. Bierczyński był dowódcą plutonu w 3. Pułku Piechoty. W ostatnich dniach sierpnia 1915 r. był jeszcze w Czerniowcach, czego dowodem jest pocztówka wysłana 27 sierpnia do rodziny w Wieliczce (w zbiorach rodzinnych zachowały się jeszcze kartki z Ottynii z 23 lutego 1915 r. oraz z Niżniowa i okolic Czerniowiec). Jesienią 1915 r. zapadła decyzja o przemieszczeniu II Brygady na Wołyń - T. Bierczyński 4 listopada 1915 r. podczas próby odzyskania z rąk Rosjan wzgórza Berezana, na północ od Kostiuchnówki, dostał się wraz z innymi - do niewoli rosyjskiej i więziony był w guberni Niżegrodzkiej nad Wołgą. Do Wieliczki powrócił w 1918 r. W latach 1919-1921 odbył służbę wojskową w 38. Pułku Piechoty Strzelców Lwowskich oraz w sztabie Dowództwa Okręgu Generalnego Lwów. W 1920 r. uzyskał na Uniwersytecie Jagiellońskim tytuł doktora praw, w 1926 r. został wpisany na listę adwokatów - kancelarię adwokacką w Wieliczce prowadził do 1939 r. i potem w latach 1945-1951. Był radnym miejskim w Wieliczce w latach 1929-1939, posłem na Sejm III kadencji z ramienia Bezpartyjnego Bloku Współpracy z Rządem w latach 1930-1935.

W latach 1928-1939 T. Bierczyński został prezesem wielickiego oddziału Związku Legionistów Polskich. W zasobie Archiwum Narodowego w Krakowie znajduje się szczątkowo zachowana dokumentacja tego oddziału z lat 1912-1939 ${ }^{8}$, zawierająca w dwóch jednostkach archiwalnych nieuporządkowane materiały (druki, maszynopisy, korespondencja, rachunki). To prawdopodobnie materiały przechowywane w bibliotece Oddziału - na niektórych dokumentach widnieje pieczątka „BIBLIOTEKA ZWIĄZKU LEGIONISTÓW POLSKICH W WIELICZCE". Wśród tej dokumentacji zachował się plik kartek z maszynopisem dziennika wydarzeń z okresu walk Legionów Polskich, a na jednej stronie jest zapis „Koniec I-szej części notatek T. Bierczyńskiego. Wieliczka, Lednica Dolna 33 (stron 121 notesu zakupionego w Żabiem)" ". Po dokładnym sprawdzeniu okazało się jednak, że są to fragmenty tekstów dwóch różnych autorów - rzeczywiście

8 ANK, zespół 29/575, Organizacje społeczne - zbiór szczątków zespołów, sygn. 29/575/24-25. Zachowały się także szczątkowe akta Oddziału w Nowym Sączu z lat 19141918, 1930-1939 (sygn. 29/575/26). Dokumentacja prawdopodobnie trafiła do Archiwum w okresie PRL i została ukryta w bibliotece.

${ }^{9}$ Lednica Dolna - wieś, od 1934 r. część Wieliczki, tam znajdował się dom Juliusza i Karoliny Heydów, wraz z obszerną posiadłością otrzymały go w spadku dwie ich córki: Wanda po mężu Bierczyńska, matka Tadeusza oraz Teresa, po mężu Gaczoł. Żabie (Wier- 
T. Bierczyńskiego oraz innego mieszkańca Wieliczki - Jerzego Hojarczyka $(1894-1951)^{10}$.

Maszynopis nosi ślady korekty, wykonanej prawdopodobnie przez T. Bierczyńskiego, wprowadzającej uzupełnienia i poprawki, można więc przypuszczać, że tekst był przygotowywany do publikacji. W okresie międzywojennym powstało dużo opracowań dotyczących historii walk Legionów Polskich, może planowano edycję wspomnień legionistów - sugeruje to informacja o zakupieniu rękopisu ${ }^{11}$.

Legioniści często prowadzili dzienniki, w których notowali zarówno przebieg działań wojennych, w których brali udział, jak i opisywali miejsca, w których przyszło im przebywać. Już w okresie międzywojennym, kiedy działalność Legionów była zarówno legendą, jak i przedmiotem badań naukowych, wiele z tych dzienników/pamiętników/wspomnień opublikowano lub wykorzystano w licznie wydawanych tekstach. Niemało z nich pozostawało jednak w zbiorach rodzinnych - czasy okupacji oraz PRL nie sprzyjały ich ujawnianiu, jednak stopniowo są one odnajdywane nie tylko $\mathrm{w}$ archiwach rodzinnych, ale w bibliotekach czy archiwach. W ramach obchodów 100-lecia odzyskania przez Polskę niepodległości wiele takich materiałów ukazało się drukiem - tytułem przykładu pochodzące z zasobu Archiwum Narodowego w Krakowie: pamiętnik Antoniego Górszczyka z Pisarzowej (1892-1980), jego częścią jest opis kampanii we Wschodnich Karpatach i na Bukowinie, gdzie walczył w szeregach Legionów Polskich ${ }^{12}$, czy też dzienniki Kazimierza Filara (1889-1918), żołnierza armii austro-węgierskiej, z działań frontowych z lat 1914-1918 ${ }^{13}$.

Nie dziwi więc, że T. Bierczyński w notesie (lub notesach) relacjonował zwyczajne i niezwyczajne wydarzenia z życia legionisty - na początku maszynopisu nazwał te zapiski pamiętnikiem, na końcu notatkami. Wydarzenia od sierpnia 1914 r. do końca maja 1915 r. ujęte zostały jako część pierwsza,

chowina) - miejscowość na Ukrainie, w okresie międzywojennym popularna miejscowość letniskowa i zdrojowa z muzeum huculskim i hodowlą koni huculskich.

${ }^{10}$ Autorzy dziękują dr. Tomaszowi Dudkowi za ustalenie autora tej części maszynopisu.

${ }^{11}$ Elżbieta Kos sewska, Związek Legionistów Polskich 1922-1939, Warszawa 2003, s. 81-92.

${ }^{12}$ O miłości Ojczyzny nie deklamowaliśmy... Wspomnienia Antoniego Sejmeja Górszczyka, oprac. Sylwester Rękas, Warszawa 2019.

${ }^{13}$ Śmieszne to życie! Ale go żal... Dzienniki Kazimierza Filara, cz. 1-2, oprac. Piotr Szlanta, Warszawa 2018. 
co pozwala przypuszczać, że także w okresie późniejszym, w tym także w niewoli rosyjskiej, nadal prowadził notatki. Niestety oryginalne notesy zaginęły, a i odnaleziony maszynopis jest niekompletny - zachowały się jedynie fragmenty obejmujące wydarzenia od 25 sierpnia do 21 października 1914 r., następnie od 10 stycznia do 9 marca 1915 r. oraz od 11 do 31 maja $1915 \mathrm{r}$.

Szlak bojowy 2. Pułku Piechoty Legionów, w którym walczył T. Bierczyński, jest doskonale znany, był wielokrotnie opisywany i analizowany. Publikacje wydane jeszcze w okresie międzywojennym ${ }^{14}$ czy materiały źródłowe z czasu działania Legionów ${ }^{15}$ pozwalają zweryfikować i potwierdzić zapisy autora. Istotne są więc nie tyle informacje o przebiegu działań wojennych $^{16}$, ale o życiu codziennym legionistów, spojrzenie na organizację działań wojskowych, wiadomości o legionistach czy opisy miejsc, w których oddziały stacjonowały.

Przygotowanie edycji tekstu maszynopisu nie nastręczało problemów w fazie przepisywania, poza trudnymi do odczytania ołówkowymi korektami czy uzupełnieniami. Zmodernizowano interpunkcję, wprowadzając przyjętą obecnie, tak aby pomogła w zrozumieniu trudnego w odbiorze stylu narracji T. Bierczyńskiego. Edycja została opatrzona licznymi przypisami, utrudniającymi może lekturę, ale umożliwiającymi rozpoznanie miejscowości i osób, przeważnie wymienionych jedynie z nazwiska. Poza wydawnictwami międzywojennymi w identyfikacji osób cenne okazały się także współczesne publikacje dotyczące Legionów ${ }^{17}$.

Ogromnym ułatwieniem przy opracowywaniu tekstu były dostępne w Internecie bazy danych, m.in.: Żołnierze Niepodległości (Muzeum Józefa Pił-

14 Józef Sitko, Zarys historii wojennej 2-go Pułku Piechoty Legionów, Warszawa 1928; T. Malinowski, M. Szumański, 2. Pułk Piechoty Legionów Polskich....

${ }^{15}$ Lista chorych, rannych, zabitych i zaginionych Legionistów do kwietnia 1915 roku, Oświęcim 1915; „Goniec Polowy Legionów. Dziennik Rozporządzeń Komendy Legionów Polskich", marzec 1915 - maj 1916, nr 1-8, 10, 12-14.

${ }^{16}$ Fragmenty komend wojskowych w języku niemieckim przetłumaczyła Pani Aldona Warzecha z Archiwum Narodowego w Krakowie, za co autorzy niniejszym dziękują.

17 Stanisław Czerep, II Brygada Legionów Polskich, Warszawa 1991; Wacława Milewska, Janusz Tadeusz Nowak, Maria Zientara,Legiony Polskie 1914-1918. Zarys historii militarnej i politycznej, Kraków 1998; Janusz Cisek, Kamil Stepan, Lista strat Legionów Polskich 1914-1918, Kraków 2006; Janus z Cis ek, Ewa Kozłowska, Łukasz Wieczorek, Słownik Legionistów Polskich 1914-1918, t. 1, Zalesie Górne 2017. 
sudskiego w Sulejówku: https://muzeumpilsudski.pl); Lista odznaczonych Krzyżem i Medalem Niepodległości (Instytut Pamięci Narodowej: https:// niezwyciezeni1918-2018.pl); Kartoteka personalno-odznaczeniowa (Wojskowe Biuro Historyczne im. gen. broni Kazimierza Sosnkowskiego: https:// wbh.wp.mil.pl/pl). Dlatego w przypisach podano jedynie dane podstawowe umożliwiające odnalezienie szczegółowych informacji o osobach -jeśli są to postaci znane, łatwo odszukać ich pełny życiorys. Jednak o ogromnej rzeszy legionistów jest niewiele informacji - tu znów pomocny może być Internet, gdzie można znaleźć np. dane o grobach wojennych cmentarza Rakowickiego w Krakowie, wśród których jest informacja o Władysławie Konstantym Petrykiewiczu (1883-1920), oficerze II Brygady Legionów. Zaś nazwisko Kazimierza Szaszewskiego (1888-1960), rotmistrza, żołnierza Legionów Polskich, widnieje na akcie objęcia Górnego Śląska przez Rząd Rzeczypospolitej Polskiej z 16 lipca 1922 r. ${ }^{18}$ Internet jest również nieoceniony przy identyfikacji miejscowości dawnej Galicji Wschodniej, które z powodu wielokrotnych modyfikacji granic państwowych Ukrainy i Rumunii w rejonie Karpat zmieniały nazwy. Podano w miarę możliwości obecną nazwę oraz przynależność państwową (niestety nie wszystkie miejscowość udało się zlokalizować).

\section{TEKST ŹRÓDŁOWY ${ }^{19}$}

[s. 1461] Pamiętnik 1914 - I część (Wieliczka)

25/VIII, wtorek. Wymarsz o 5-tej po południu, nabożeństwo, muzyka gra solenne marsze, rynek zabity publiką, która sypie kwiaty, a co czulsze serca ronią łzy. Burmistrz ${ }^{20}$ żegna nas ognistą przemową, na którą odpowiadam krótko, kończąc okrzykiem: Niech żyje wolna i niepodległa Polska! ${ }^{21}$

a dopisane ołówkiem

${ }^{18}$ Oryginał aktu przechowywany w Archiwum Państwowym w Katowicach został w 2018 r. wpisany na Krajową Listę Programu UNESCO Pamięć Świata i w związku z tym jest prezentowany w Internecie, https://katowice.ap.gov.pl (odczyt: 02.03.2020).

${ }^{19}$ ANK, Organizacje społeczne - zbiór szczątków zespołów, sygn. 29/575/24, s. 1461-1499.

${ }^{20}$ Franciszek Aywas (1862-1940), burmistrz Wieliczki w 1. 1905-1914, 1918-1934, w 1. 1904 1913, 1919-1921 prezes Polskiego Towarzystwa Gimnastycznego „Sokół” w Wieliczce, Wojciech Gawroński, Stownik biograficzny wieliczan, Muzeum Żup Krakowskich, Wieliczka 2008, s. 12-13.

${ }^{21}$ Pożegnanie ,wielickich sokołów” opisał w pamiętniku także Franciszek Widomski (18931981), pracownik umysłowy wielickiej Kopalni Soli, działacz niepodległościowy, społeczny i kulturalny. Zanotował on m.in., że Emanuel Winter skierował do druhów słowa pożegnania w imieniu 
Wśród deszczu kwiatów i okrzyków, dźwięków muzyki maszerujemy. Na Glinikach ${ }^{22}$ fotografia, która się naturalnie nie udała. Dalejże na Rżąkę̧23, tu całuję się z dubeltówki $\mathrm{z}$ jednym i drugim $\mathrm{p}$. Winterami ${ }^{24}$ i innemi osobami płci męskiej. $\mathrm{Z}$ marszem Sokołów na ustach odmaszerowujemy do Krakowa. Tu melduję się u Rucińskiego ${ }^{25}$, dostajemy kapuśniak i kwaterę na ulicy św. Jana u Sióstr Prezentek ${ }^{26}$.

Z drużyny naszej, bocheńskiej, podgórskiej, niepołomickiej i skawińskiej tworzą II drużynę i tak co dzień rano idziemy do Sokoła ${ }^{27}$, stąd na Błonia, w południe powrót na kwatery rynsztunek zdejm, uchwyć za menażki i do Sokoła na obiad, po południu na ćwiczenia do Sokoła, potem stanie na boisku, kolacja, stanie na boisku, rozkaz i około 9, 91/2 na kwaterę. To strasznie nas męczyło, potem z wolna nieznacznie stosunki się poprawiały, a może ludzie się do nich przyzwyczaili. Komendantem naszym został p. Słuszkiewicz ${ }^{28}$, naczelnik z Bochni. Niedziela zwykle wolna, czasem nabożeństwo, więc za „przezczasem”, albo i bez, hajda do miłej Wieliczki. W drugim tygodniu zostałem kapralem i w tej randze komendantem plutonu, naszym półbatalionowym kom. Roja ${ }^{29}$. Na Błoniach aż do znudzenia marsze w kolumnie, masie, raporty, defilady i tem podobne parady, tyraliery niewiele, stosowanych ćwiczeń nic, na baczność stój jak mur, na stój jakby cię piorun trzasł i tak w koło Macieju, wiara tylko patrzy, kiedy spoczynek i na obiad wyrwać się do miasta. Kompanię ciągle się porządkuje, przydzielono nam 50 z kadrów uzupełniających i Tąkla ${ }^{30}$,

wielickiego oddziału Polskiego Komitetu Narodowego, a potem głos zabrał Tadeusz Bierczyński, który dziękując miastu i powiatowi za pomoc udzieloną sokolej drużynie, zapewnił w jej imieniu wypełnienie do końca honorowych zadań żołnierskich dla świętej sprawy oswobodzenia z niewoli całej Polski. Zakończył słowami z „Roty” Marii Konopnickiej: „Tak nam dopomóż Bóg!”, Fragmenty nieopublikowanego pamiętnika Franciszka Widomskiego w zbiorach A. Gaczoła.

${ }^{22}$ Gliniki - przysiółek w północno-zachodniej części Krzyszkowic, wsi koło Wieliczki na granicy z Rżąką i Krakowem (obecnie pod częściej stosowaną nazwą Glinki, część osiedla Wieliczka-Krzyszkowice u zbiegu ulic Ochota i Krakowska).

${ }^{23}$ Rżąka - wieś pomiędzy Prokocimiem, Bieżanowem, Piaskami Nowymi, Piaskami Wielkimi oraz Wieliczką, obecnie część Krakowa.

${ }^{24}$ Emanuel Winter (1858-1923), ur. w Zakopanem, notariusz w Wieliczce w 1. 1908-1923, marszałek Rady Powiatowej Powiatu Wielickiego, wiceburmistrz, prezes Polskiego Towarzystwa Gimnastycznego „Sokół” w 1. 1913-1919, komendant Ochotniczej Straży Pożarnej, W. Gawroński, Stownik biograficzny..., s. 192-193.

${ }^{25}$ Szczęsny Ruciński (1867-1944), naczelnik Towarzystwa Gimnastycznego „Sokół” w Krakowie 1894-1914, dowódca II batalionu 2. Pułku Piechoty Legionów.

${ }^{26}$ Klasztor Prezentek (Zgromadzenie Panien Ofiarowania Najświętszej Marii Panny) przy ul. św. Jana 7.

${ }^{27}$ Siedziba krakowskiego Towarzystwa Gimnastycznego „Sokół” mieściła się przy ul. Wolskiej 27 (obecnie ul. J. Piłsudskiego).

${ }^{28}$ Jan Słuszkiewicz (1876-1957), inżynier, dowódca ochotników bocheńskich przybyłych do Krakowa, w Legionach jeden z dowódców saperów budujących w październiku 1914 r. w Karpatach Wschodnich Drogę Legionów przez przełęcz ponad wsią Rafajłowa, Kazimierz Taczanowski, Podpułkownik Jan Stuszkiewicz, „Wiadomości Bocheńskie” 2018, R. 30, nr 4 (118), s. 14-15.

${ }^{29}$ Bolesław Jerzy Roja (1876-1940), oficer armii austro-węgierskiej, w Legionach w stopniu kapitana (od listopada 1914 r. major, od marca 1915 r. podpułkownik).

${ }^{30}$ Prawdopodobnie Bolesław Tąkiel (1893-1915), chorąży 7. kompanii II baonu 2. Pułku Piechoty, poległ 7 czerwca 1915 r. pod Rarańczą. 
który dostał pluton, a ja poszedłem na prawoskrzydłowego kaprala do I-go plutonu. Kwaterę przeniesiono nam na Kotłowe ${ }^{31}$, gdzie kilku z nas ulokowało się u p. Tatzreiterów w „szalanie". Koło 15-go zostałem rachmistrzem kompanii na miejsce Semętkowskiego, który poszedł do kancelarii pułkowej i zaczęły się dla mnie spisy takie i owakie, tego i owego to dla kompanii, to dla batalionu, to dla pułku i chodzenie do tej skandalicznej odprawy, która kończyła się najwcześniej o 10 wieczorem - rano o 5-tej [s. 1462] pobudka i cały dzień na nogach. Około 20-go wzięli nam Słuszkiewicza, który został oficerem pionierów, a myśmy dostali Petrykiewicza ${ }^{32}$ (ppor) ${ }^{\mathrm{a}}$.

23-go byłem ostatni raz w Wieliczce, zaczęły chodzić pogłoski, że pójdziemy wnet. Baczyński ${ }^{33}$ wystosował siarczysty manifest i zakończył słowami: Nad wami Orły Polskie i Sława Legionów!

Ano, 29-go wieczorem na gwałt kazali nam pisać kartki pośmiertne ${ }^{34}$, do których kapsli nie dali. 30/IX cały dzień pakowanie. Mama przyjechała w południe, udało mi się Ją uspokoić, a nawet dobrze usposobić. O szóstej wieczorem okolicznościowe nabożeństwo z kazaniem w kościółku Prezentek ${ }^{35}$ i wymarsz na dworzec towarowy, naturalnie nie tam, skąd mieliśmy siadać. Było to we środę wieczorem. Parę dni przedtem ubrano nas na austriacko „ganz”, dano bieliznę, trykoty etc. Parę minut przed jedenastą ruszamy w stronę Płaszowa $^{36}$, o 3-ciej już byliśmy w Kalwarii ${ }^{37}$, o 8-mej w Suchej ${ }^{38}$ i w tem tempie jechaliśmy dalej, tj. coraz wolniej. Mijamy Żywiec ${ }^{39}$, Csaczęę, gdzie dowiaduję się, że pójdę do linii, a moim następcą będzie Kozłowski ze Skawiny, tymczasem ma się przy mnie zaprawiać. 2 nasi komendanci plutonów p. Tąkiel ${ }^{41}$ i Hubicki $^{42}$ przed wyjazdem z chorążych zostali plutono-

a dopisane ołówkiem

${ }^{31} \mathrm{Na}$ Kotłowem - budynek Cechu Rzeźników i Masarzy przy ul. A. Potockiego 18 (obecnie ul. Westerplatte). Cech dysponował pokojami biurowymi i salami reprezentacyjnymi, część pomieszczeń była wynajmowana instytucjom i osobom prywatnym.

${ }^{32}$ Władysław Konstanty Petrykiewicz (1883-1920), oficer II Brygady.

${ }_{33}$ Rajmund Baczyński (1857-1929), generał major armii austro-węgierskiej, dowódca Legionu Zachodniego, a następnie Legionu Polskiego (20 sierpnia - 1 października 1914 r.), komendant Twierdzy Kraków.

${ }^{34}$ Nieśmiertelniki - identyfikatory żołnierzy na wypadek śmierci lub zranienia.

${ }^{35}$ Kościół pw. św. św. Janów Chrzciciela i Ewangelisty, położony na rogu ulic św. Jana i św. Tomasza.

${ }^{36}$ Płaszów - wieś na prawym brzegu Wisły na południowy wschód od Krakowa, od 1912 r. część Krakowa, towarowy węzeł kolejowy Podgórze-Płaszów na linii kolejowej Kraków-Lwów (Galicyjska Kolej Karola Ludwika), połączony linią do Oświęcimia z Galicyjską Koleją Transwersalną przebiegającą przez rejon Karpat.

${ }^{37}$ Kalwaria Zebrzydowska - miasto w województwie małopolskim w powiecie wadowickim, zbiegały się tu linie kolejowe z Krakowa do Żywca i do Bielska-Białej.

${ }^{38}$ Sucha Beskidzka (wcześniej Sucha) - miasto w województwie małopolskim, węzeł kolejowy Kolei Transwersalnej (z Żywca przez Nowy Sącz do Husiatyna), z odgałęzieniem do Krakowa.

${ }^{39}$ Żywiec (niem. Saybusch) - miasto w województwie śląskim, węzeł kolejowy na trasie do Bielska (odnoga Kolei Północnej Cesarza Ferdynanda) oraz Kolei Transwersalnej.

${ }^{40}$ Csacza, Czadca (dawniej Czaca, słow. Čadca, węg. Csaca, Csáca) - miasto w północnej Słowacji w kraju żylińskim, węzeł kolejowy Kolei Transwersalnej.

${ }^{41}$ Bolesław Tąkiel.

${ }^{42}$ Prawdopodobnie Kazimierz Hubicki. 
wymi, poszli do super i pożegnali Legiony. Na dwa tygodnie przed wyjazdem z Krakowa wzmógł się ruch do superrewizji ${ }^{43}$, ludzie wprost prosili o nią. Tak uciekł bestia Karol w przeddzień wyjazdu, a Zygma się strasznie na niego oburzał.

Z Csaczy do Uj-Zsolny ${ }^{44}$, stąd nocą do Rosahegy ${ }^{45}$. Po drodze miałem z Adamem ${ }^{46}$ rozmowę dziwną i romantyczną, wśród której wyszły na wierzch rzeczy, o których istnieniu nawet by się filozofom nie śniło. Na tem tle napisałem do $Z{ }^{47} \mathrm{z}$ Margitfalvy ${ }^{48}$ kartkę mocno niezrozumiałą, moja wina!, która Jej no i mnie na parę dni przysporzyła kłopotu. W Margitfalvie staliśmy dzień cały prawie, ja koło południa pojechałem do Koszyc ${ }^{49}$, do których zwożono pociągi chorych, między innymi i choleryków. Widziałem parę trupów i kilka kariolek sanitarnych ${ }^{50}$, w których na pół siedzieli, na pół leżeli niemiłosiernie pokręceni chorzy. Z Koszyc zaczęliśmy szybciej jechać do Saturlja-Ujhely ${ }^{51}$, gdzie dowiedzieliśmy się, że nieprzyjaciel blisko, że może być napad na pociąg! P. Petrykiewicz w natchnionym sposobie dawał instrukcje wojenne i wyliczał przewinienia, za które kula w łeb. W Csap ${ }^{52}$ nabijam z flegmą karabin - mam zostać rachmistrzem. Nagle dowiadujemy się o 8-mej wieczorem, że można spać spokojnie do 4-tej rano, przechodzę z tą miłą wieścią cały [s. 1463] pociąg i układam się do snu. Pociąg rżnie z szybkością $80 \mathrm{~km}$ na godzinę. Na rano dojeżdżamy do Nagy-Banya ${ }^{53}$, linia odjeżdża prędzej, my w godzinę za niemi, ludzie czę-

${ }^{43}$ Superrewizja - dodatkowa weryfikacja stanu zdrowia wojskowych i ich przydatności do dalszego udziału w działaniach wojennych.

${ }^{44}$ Żylina (słow. Žilina, węg. Zsolna) - miasto w północnej Słowacji, węzeł kolejowy Kolei Transwersalnej.

${ }^{45}$ Rużomberk (słow. Ružomberok, węg. Rózsahegy) - miasto w środkowej Słowacji w kraju żylińskim, stacja linii kolejowej z Popradu do Żyliny.

${ }^{46}$ Młodym legionistą, który z Wieliczki wyruszył w drużynie dowodzonej przez T. Bierczyńskiego, był Adam Baziak urodzony w Wieliczce w 1893 r., pracownik wielickich salin, Spis byłych żolnierzy Legionów Polskich opracowany w 1973 r. przez mgr. inż. Władysława Rzepeckiego oraz ptk. dypl. Władystawa Jamke, [w:] Jadwiga Duda, 131 spotkanie z cyklu ,Wieliczka-Wieliczanie”. W 90. Rocznicę odzyskania przez Polskę Niepodlegtości (1918-2008). Udział Wieliczan w walce o Niepodległość, Biblioteczka Wielicka z. 76, Wieliczka 2008, s. 34.

${ }^{47}$ Prawdopodobnie Zofia Piestrakówna, córka Feliksa Piestraka (1868-1947), inżyniera górniczego, zarządcy kopalń, badacza dziejów górnictwa solnego, w 1. 1909-1924 dyrektora Szkoły Górniczej i Muzeum Salinarnego w Wieliczce. Franciszek Widomski w pamiętniku zapisał, że Bierczyński zamierzał się starać o rękę Zofii P. i listy do niej przesyłał z frontu za pośrednictwem przyjaciela, autora pamiętnika, Fragmenty nieopublikowanego pamiętnika w zbiorach A. Gaczoła.

${ }^{48}$ Margecany (węg. Margitfalva) - wieś na Słowacji w kraju koszyckim, stacja linii kolejowej Kolei Koszycko-Bogumińskiej.

${ }^{49}$ Koszyce (słow. i czes. Košice, węg. Kassa) - miasto we wschodniej Słowacji, węzeł kolejowy.

${ }^{50}$ Jedno z potocznych określeń karetki sanitarnej (ambulansu), z włos. carreta, carriuolai - stąd karjulka czy karjolka.

${ }^{51}$ Sátoralja újhely (słow. Nové Mesto pod Šiatrom) - miasto w północno-wschodnich Węgrzech, stacja kolejowa Pierwszej Węgiersko-Galicyjskiej Kolej Żelaznej łączącej Galicję z Węgrami.

${ }^{52}$ Czop (węg. Csap) - miasto w obwodzie zakarpackim Ukrainy w pobliżu zbiegu granic Ukrainy, Węgier i Słowacji, węzeł kolejowy na trasie do Lwowa, Koszyc i Budapesztu.

${ }^{53}$ Baia Mare (węg. Nagybánya) - miasto w Rumunii w okręgu Marmarosz, stacja kolejowa. 
stują nas jabłkami, słoniną, chlebem, papierosami etc. Baby po drodze płaczą i łamią ręce. Stajemy w Felsőbanya ${ }^{54}$ koło 10 -tej, tren ${ }^{55}$ układa się do 5-tej po południu.

Nasza kompania poszła na patrole, pogubiła się prawie cała, tylko Małysa Władek doszedł do Kraczfalva ${ }^{56}$. Reszta wróciła. Wiara porzucała koce, buty, bieliznę, całe tornistry. Gibiński ${ }^{57}$ spotkał się z trenem (furmani same Wołochy ${ }^{58}$ lub Żydy) i szedł jako zabezpieczenie. Droga dobra, tylko przeklęte, długie serpentyny. Na przełęczy stajemy o 1-szej w nocy i zjazd po coraz gorszej drodze na dół do 5-tej. Straszne znużenie mnie ogarnia, rano gotowanie śniadania, którego kompania nie je, bo idzie na „wroga”. Gotuje się dla nich obiad, którego nikt nie je, bo nie ma nikogo. Ja śpię na kopie siana do 12-tej. Po południu alarm, że jesteśmy otoczeni - ludzie w każdym człowieku widzą Kozaka, w każdym stuknięciu słyszą strzały karabinowe, tren z biedą wyjeżdża na drogę. Schodzi się z nami Petrykiewicz z resztą kompanii. O 7-mej wśród ohydnego deszczu i chłodu ruszamy niewyspani i podminowani - przed Gyulafalu ${ }^{59}$ w kukurydzianem polu, oświeconem skąpo przez przezierający przez chmury księżyc, nawet widzą Kozaków. Stajemy we wsi, nagle po jakim półgodzinnym postoju od końca trenu strzały coraz gęstsze, wiara zeskakuje z wozów i poprzez wozy z rowu, ja także, strzela przed siebie, wystrzeliłem, nie wiadomo po co, 3 naboje. $Z$ początku zdawało mi się, że wzdłuż wozów pędzą Kozacy, a to konie spłoszone taki ruch zrobiły. Ale gorzej z tego - kompanie kwaterujące usłyszały strzały, nadbiegły, obsadziły mostek i rzeczkę, a nie wiedząc, co jest, poczęły strzelać. I tak zabili rachunkowego 7-mej komp. Łagiewskiego ${ }^{60}$, człowieka spokojnego, który uśmiechał się tylko czasem, a mało mówił. W ten sam dzień pasjans wywróżył mu, że cało i zdrowo wróci z wojny. Prócz tego postrzelono jednego, jednego konia zabito i jednego postrzelono. Tej samej nocy na 2 godziny przedtem napadło z zasadzki z pola kukurydzianego kilkunastu Kozaków na nasz baon, który rozwinął się bezładnie i rozpoczął piekielny ogień. Kozacy strzelili ze 2 razy i zemknęli, zostawiając 2 zabitych i 3 konie. Nasi postrzelali się wzajem, było coś 8 zabitych i kilkunastu rannych. Zygma dostał ataku serca, a Miczyński ${ }^{61}$ wśród ognia kompletnie zgłupiał. Potem już szli z trenem. Działo [s. 1464] się to $\underline{6 / X}$ we wtorek. Następnego dnia rano w placówkach stojących na górach widzą Kozaków, śpię na ganku. Przez Bardfalva ${ }^{62}$, gdzie na gwałt wyszukują ukrytych Kozaków i jawnych moskalofilów, wjeżdżamy wieczorem wśród huku dział pod Marmaros-Szigeth ${ }^{63}$ do Farkas-rev ${ }^{64}$, gdzie stoimy przeszło tydzień wśród ustawicznej niepogody. Drugi pluton przydzielony do baonu

${ }^{54}$ Baia Sprie (węg. Felsőbánya) - miasto w Rumunii w okręgu Marmarosz, stacja kolejowa.

${ }^{55}$ Tren - tabor wojskowy.

${ }^{56}$ Mara (węg. Krácsfalva) - wieś w Rumunii w okręgu Marmarosz.

${ }^{57}$ Prawdopodobnie Stanisław Gibiński.

${ }^{58}$ Wołochy, Wołosi - określenie ówczesnych Rumunów oraz Mołdawian należących do grup etnicznych pochodzenia wołoskiego zamieszkujących Półwysep Bałkański.

${ }^{59}$ Giuleşti (węg. Gyulafalu) - miejscowość w Rumunii w okręgu Marmarosz.

${ }^{60}$ Karol Zygmunt Łagiewski (1877-1914), ceramik (?), sierżant 7. kompanii 2. Pułku Piechoty.

${ }^{61}$ Zygmunt Miczyński (1895-1939), student Wydziału Lekarskiego UJ, właściciel Apteki Salinarnej w Wieliczce, którą odziedziczył po ojcu, Spis byłych żołnierzy Legionów Polskich ..., s. 35.

${ }^{62}$ Berbeşti (dawniej Bardfalva, węg. Bárdfal) - wieś w Rumunii w okręgu Marmarosz.

${ }^{63}$ Syhot, Syhot Marmaroski (rum. Sighetu Marmației, węg. Máramarossziget, Sighet) - miasto w Rumunii w okręgu Marmarosz przy granicy z Ukrainą nad rzeką Cisą.

${ }^{64}$ Farkasrev - wieś w Rumunii w okręgu Marmarosz. 
Januszajtisa ${ }^{65}$ przeżywa wszystkie przyjemności wojny, głód, chłód, brodzi po pas w rzece, a nikt się o nich nie stara. W sobotę wieczorem cichy alarm, wszystko rusza z wyjątkiem trenu. Maszerują przez Ronaszeg ${ }^{66}$, Obczynę (góra) ${ }^{67}$ do Vissovölgy ${ }^{68}$, skąd Rosjanie po wysadzeniu mostów drogowego i kolejowego i po spaleniu kompletnem wsi umknęli. Myśmy w niedzielę w nocy wyjechali tak, że na trzecią byliśmy na miejscu. Huk wysadzanego do reszty mostu przez naszych pionierów trochę nas zaniepokoił.

Na drugi dzień, koło 13/X jedziemy z powrotem do Szigethu, w nocy odpoczywamy parę godzin (w Szigecie) ${ }^{\mathrm{a}}$ i wyjeżdżamy, błądząc trochę do Taraczköz ${ }^{69}$. Nad Cisą ${ }^{70}$ najcudowniejszy wschód słońca, jaki widziałem w życiu - niczem Gierymski ${ }^{71}$. W Nagy-Bocsko $^{72}$ (przed Szigethem) pobojowisko, wieś żydowska zrabowana prze moskalofilów, których wyłapywano. Koło Taraczköz zabite i wyobżerane konie, kręgosłupy końskie, pies zabity! Z Taraczköz wśród ślicznej pogody do Nyreshaza ${ }^{73}$ kompania pojechała koleją z Vissvölgy do Taraczköz, stąd kolejką wąskotorową do Nyreshaza. Z Farkasrev zemkli przez superrewizję Z. Miczyński na anemię kiszek, Zygma na serce. Adam i kupa Podgórzaków zaczyna się systematycznie kiwać, prowadząc z Petrykiewiczem nużącą walkę podjazdową. Z Nyreshaza przez Dombo ${ }^{74}$ do Königsfeldu (Kiralymező) ${ }^{75}$, niemiecka osada, cudna jesień - tu zjeżdżamy się z Excelencją Durskim ${ }^{76}$ i całym sztabem, który oświadczył, że nasz tren: das ist ein Spital für Hebammenkurs ${ }^{77}$ i zastraszył nas okropnem przejściem przez „Pantyr”78, że będziemy musieli przenosić bagaże na rękach - śliczna perspekty-

a dopisane ołówkiem

${ }^{65}$ Marian Januszajtis-Żegota (1889-1973) - komendant Polskich Drużyn Strzeleckich (19121914), ostatni dowódca I Brygady Legionów Polskich (1916-1917).

${ }^{66}$ Rónaszék - wieś w Rumunii w okręgu Marmarosz.

${ }^{67}$ Obczyna - góra wznosząca się nad wsią Visóvölgy w Rumunii w okręgu Marmarosz.

${ }^{68}$ Visóvölgy - wieś w Rumunii w okręgu Marmarosz.

${ }^{69}$ Tereswa (węg. Taracköz) - miejscowość w obwodzie zakarpackim Ukrainy.

${ }^{70}$ Cisa - rzeka w środkowej Europie, lewostronny dopływ Dunaju, przepływa przez Ukrainę, Węgry i Serbię.

${ }^{71}$ Prawdopodobnie mowa o obrazie „Krajobraz o wschodzie słońca - przedświt” Maksymiliana Dionizego Gierymskiego (1846-1874) - malarza, współtwórcy polskiego realistycznego malarstwa pejzażowego XIX w., starszego brata Aleksandra Gierymskiego.

${ }^{72}$ Velykyi Bychkiv (węg. Nagybocskó, Nagybocska) - miejscowość w obwodzie zakarpackim Ukrainy.

${ }^{73}$ Neresznica (węg. Nyéresháza) - miejscowość w obwodzie zakarpackim Ukrainy.

${ }^{74}$ Dibov (węg. Dombó) - miasto w obwodzie zakarpackim Ukrainy.

${ }^{75}$ Ust-Czorna (niem. Königsfeld, węg. Királymező) - miejscowość w obwodzie zakarpackim Ukrainy.

${ }^{76}$ Karol Trzaska-Durski (1849-1935) - generał armii austriackiej, od 23 września 1914 r. do grudnia 1915 r. komendant Legionów Polskich z ramienia Austrii. Legiony od 11 października 1914 r. wchodziły w skład grupy operacyjnej dowodzonej przez gen. Karla von Pflanzera-Baltina, podobnie jak austriacko-węgierska 54. dywizja piechoty dowodzona przez generała Emila Schultheissa.

${ }^{77}$ Das ist ein Spital für Hebammenkurs (niem.) - to jest szpital dla kursu położnych.

${ }^{78}$ Pantyr - szczyt w Karpatach Wschodnich w głównym paśmie Gorganów, położony przy przełęczy ponad wsią Rafajłowa, na której w październiku 1914 r. powstała Droga Legionów. 
wa! Suniemy do Brusztury ${ }^{79}$, a nasza kompania do Bistrikowa ${ }^{80}$, skąd się jeździ co dzień do odprawy i fasunku. Tu wieczorem otrzymuję 2 pierwsze kartki z domu i od Antka ${ }^{81}$ ! później nadchodzą inne. Koło $\underline{20 / X}$ do Holzschlaghausu ${ }^{82}$ wśród uroczej doliny, spanie w szałasach, wieczorem dziesiątki ognisk, a w dymach włóczą się czarne sylwetki ludzi. Ktoś przyrównuje obóz do cmentarza w dniu Zadusznym. Na drugi dzień przeprawa przez Pantyr po drodze z okrąglaków ułożonej specjalnie... ${ }^{a}$

[s. 1465] [Prawdopodobnie 9.01.1915] ... go pokoju, meblujemy elegancko, lustro pod powałę, kanapy, fotele etc. Obiad znakomity, zupa jarzynowa, pieczeń z buraczkami i czarna kawa. Po południu nadchodzi tych 5-ciu, przynoszą kury, które zjadamy na kolację i znowu w karty - zabawne życie.

10/I, niedziela - ludzie się mają ukąpać, bo około 1-szej alarm, mamy się bawić we wojnę - nici z tego, „zwiedzamy” szczegółowo Ökermezö ${ }^{83}$, szczególnie bóżnicę obok naszego „salonu” w całem tego słowa znaczeniu. Pokój, w którym granat wpadł przez dach (nie wiadomo, którędy), wybuchł na strychu, wyrwał potworną dziurę w powale i trochę uszkodził ścianę, ani szyb nie wybił, ani szaf nie uszkodził. Znowu gramy w preferka ${ }^{84}$, coś przerżnąłem z 50 koron, dziwne szczęście. Komendy baonów dostają rozkaz wymarszu do Huszt $^{85}$, tam mają rozkaz odpieczętować, a drugi w chwili wyjazdu.

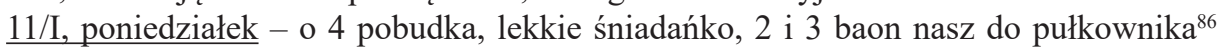
do Vucskomező (Łuczkowa) ${ }^{87}$, stąd furami - piekielna jazda, zimno, o 10 wieczorem już byliśmy w Huszt. Kiepskie kwatery, my do hotelu Korona, nie ma co jeść prawie, w drugim oświadczają nam, że: Herr schläft, Frau schläft ${ }^{88}$ i dają do zrozumienia, że nas nie trzeba, w sklepach kupujemy drobiazgi. Szukamy kwatery, po drodze znajdujemy krawca, zamawiam spodnie, o 2-giej zachodzimy do Żyda, pijemy kiepską kawę, jemy orzechy i jabłka, idziemy spać do nieopalonej komórki na żydowskie bety - to jest miasto! niech pieron strzeli!

a brak kilku kartek maszynopisu

${ }^{79}$ Lopuhiv (węg. Brusztura) - wieś w obwodzie zakarpackim Ukrainy.

${ }^{80}$ Bistrikov - osada w obwodzie zakarpackim Ukrainy.

${ }^{81}$ Antoni Kazimierz Mikuła (1891-1915) pochodził z Wieliczki, podobnie jak T. Bierczyński był studentem Wydziału Prawa Uniwersytetu Jagiellońskiego, zmobilizowany do armii austro-węgierskiej zdołał uzyskać przeniesienie do Legionów Polskich, zginął pod Bieczem 4 maja 1915 r., Spis bytych żotnierzy Legionów Polskich..., s. 35.

${ }^{82}$ Holzschlaghaus - osada strażnika leśnego w dolinie potoku Płajska, $15 \mathrm{~km}$ na północ od wsi Brusztura.

${ }^{83}$ Miżhirja (wcześniej Wołowe Pole, węg. Ökörmező) - miejscowość w obwodzie zakarpackim Ukrainy.

${ }^{84}$ Preferans - gra w karty, zwykle dla trzech osób talią 32-kartową, podobna do wista, popularna zwłaszcza na przełomie XIX i XX w.

${ }^{85}$ Chust (węg. Huszt) - miasto w obwodzie zakarpackim Ukrainy.

${ }^{86}$ Zygmunt Zieliński (1858-1925), pułkownik armii austro-węgierskiej, 6 sierpnia 1914 r. w Krakowie zgłosił się na ochotnika do Legionów Polskich, został organizatorem i pierwszym dowódcą 2. Pułku Piechoty, od 8 stycznia 1915 r. był przez pewien czas komendantem Legionów.

${ }^{87}$ Vuczkovje (węg. Vucskómező) - miejscowość w obwodzie zakarpackim Ukrainy.

${ }^{88}$ Herr schläft, Frau schläft (niem.) - pan śpi, pani śpi (gospodarze). 
12/I, wtorek - na drugi dzień chodzimy po mieście i kupujemy różne specjały, przeważnie do jedzenia, i szampan i wino i wódkę i ciastka, daktyle, sery etc. Tylko zjeść coś to trudno dostać, a jak się dostanie to drogo i takie świństwo aż hej. Człek się wykąpał, ostrzygł, w ogóle zrobił się przyjemnym, a wieczór do kina, zadziwiająco niezrozumiałe dramaty i dziwnie głupie, ale rozbrajające naiwnością komedie.

13/I, środa - rano pobudka o 7-mej, na stację, gdzie nas zawagonowali coś o 5-tej po południu. Podobno, a raczej na pewno idzie wiele wojska pruskiego, kawaleria, która była pod Paryżem o $18 \frac{1}{2} \mathrm{~km}$. Zafasowałem srebrnego kutasa ${ }^{89}$ od Kazia Szaszewskiego ${ }^{90}$, który konie[s. 1466]cznie chce się dostać do naszej kompanii, kiepskie spanie we $4 \mathrm{w}$ jednem coupée.

14/I, czwartek - mieliśmy jechać do Felsövisso ${ }^{91}$, stąd iść do Alsovisso ${ }^{92}$, gdzie się nam patrzył odpoczynek coś 10 dniowy, aleśmy sobie odpoczęli w pociągu i zawieźli nas do Borsza ${ }^{93}$ (stąd w prostej linii wychodzi się na Kimpolung ${ }^{94} \mathrm{w}$ płd. Bukowinie). Tu już zastajemy baterię ciężkich haubic z Krakowa, pakujemy się gdzieś za Borszę, pokazuje się, żeśmy zbłądzili, ale się wracamy, nadrabiając $4 \mathrm{~km}$, idziemy do Borszabanya ${ }^{95}$, tu mam służbę garnizonową, wesoło się nam wiedzie.

15/I, piątek - popijamy różne rzeczy, skądś nawet dorwali nasi ordynansi absyntu, ale to świństwo, niech się Anglicy tem trują. Aż dwa razy fotografowaliśmy się niby „oficerowie" II Baonu. Dosyć dużo ochotników przyplątało się do Legionu w Huszt - Węgrzy, kogo w tych Legionach nie ma, Niemcy, Węgrzy, a pono idzie coś kompania Żydów. Nie powinienem grać w karty, znowu „coś” trochę przegrałem.

16/I, sobota - Jamróz Roman ${ }^{96}$ przestrzelił rano w czasie zbiórki stopę, szczęściem nie naruszył kości. Zbiórka, za karę powtórka zbiórki o 10-tej, potem cały dzień nic do roboty, a więc znowu do preferansa, przerżnąłem parędziesiąt koron, wieczorem upiliśmy na śliwowicy biednego Kruszynę.

17/I, niedziela - zbiórka, msza, jazda do Borsza, ledwieśmy znaleźli kwaterę u jakiegoś jegra, wsiadać na furmanki, jazda na Prisłop ${ }^{97}$. Pod Prisłopem pułkownik, który maszerował z I i III baonem, dogonił nas, kazał zsiąść i niezmiernie rozdrażniony krzyczał: maszerować

\footnotetext{
${ }^{89}$ Kutas, chwast - ozdoba w postaci pędzla z nici lub sznureczków na końcu sznura przypinanego do pasa jako element dekoracyjny stanowiący dolne wykończenie bogatych szamerunków stosowanych w mundurach wojskowych.

${ }^{90}$ Kazimierz Szaszewski (1888-1960), rotmistrz, żołnierz Legionów, późniejszy adiutant gen. Stanisława Szeptyckiego, w okresie międzywojennym prezes Oddziału Związku Legionistów Polskich w Busku-Zdroju lub Kazimierz Saszewski (1891-1939), pochodzący z Wieliczki student Politechniki Lwowskiej, żołnierz 2. Pułku Piechoty, następnie 2. Pułku Ułanów II Brygady, rotmistrz rezerwy 2. Pułku Szwoleżerów, Spis byłych żolnierzy Legionów Polskich ..., s. 36.

${ }^{91}$ Felsövisó - miasto w Rumunii w okręgu Marmarosz.

${ }^{92}$ Alsóvisó - wieś w Rumunii w okręgu Marmarosz.

${ }^{93}$ Borşa (węg. Borsa) - miasto w Rumunii w okręgu Marmarosz.

${ }^{94}$ Kimpolung Mołdawski - miasto w Rumunii w okręgu Suczawa nad rzeką Mołdawą.

${ }^{95}$ Borsabánya - miejscowość w północnej Rumunii w okręgu Marmarosz.

${ }^{96}$ Roman Jamróz, wieliczanin, pracownik warsztatów w wielickich salinach, Spis byłych żołnierzy Legionów Polskich ..., s. 35.

${ }^{97}$ Prislop, Przysłop (rum. Pasul Prislop) - przełęcz na wysokości 1418 m n.p.m., obecnie na terenie Rumunii (przez przełęcz biegnie droga krajowa łącząca Borșę z miejscowością Kimpulung
} 
szósta, a tu wozów pełno, jucznych koni. Nareszcie dostaliśmy się na Prisłopu, tu stoimy na mrozie ze 2 godziny, coś tam fasujemy, potem kwatery, prowadzi nas żandarm, naturalnie węgierski, po śnieżnych polach wzdłuż ciężkich haubic. Nareszcie nic, wracamy, chodzimy tu i tam. Nareszcie prowadzą nas do baraku dla nas przeznaczonego. Był o kilkadziesiąt kroków od miejsca naszego postoju, śpimy od 12 1⁄2, zimno budzi mnie o 2 1/2, siedzę przy ognisku i drzemię.

$\underline{18 / \mathrm{I}}$ - o 6 zbiórka, bez śniadania marsz, przyłączyli do nas przeznaczone dla II baonu 1/2 IV kompanii z baonu uzupełniającego z kom. Rybakiem ${ }^{98}$ (2 plutony), dajemy im naboje, bez spoczynku i jedze[s. 1467]nia maszerujemy. My mamy być rezerwą dywizji!? III baon poszedł po drodze w góry na pozycje, I został gdzieś w tyle. Idziemy z pułkownikiem i przychodzimy, stajemy pod komendą dywizji, armaty grzmocą tuż nad uchem, co za frajda! Konie skaczą! Excelencja austriacki ${ }^{99}$ daje rozkaz, żeby kompania natychmiast szła, bo Mochy ${ }^{100}$ posuwają się doliną i nasza kawaleria ich powstrzymuje, my idziemy ich zluzować. Pułkownik: ano panowie co jeszcze nie byli w ogniu, pokażą, co umią, a i ci panowie, co byli w ogniu, tyż pokażą, co umią, poczem w sposób dla siebie charakterystyczny wyjaśnił sytuację: a jeden cug wyśle pon na tę górkę za potoczkiem, na tę pirszą, rozumiesz pon? no pamiętajcie, żeście Polaki! Ja idę na tę górkę, dostałem się tam o 2-giej, mieliśmy tamtędy nie przepuścić nacierających Moskali ${ }^{101}$. Zaraz zaczęły nad nami skądś gwizdać kule i gwizdały do 5-tej, nie robiąc szkody. Z góry zaczęli widocznie schodzić Austriacy i na tem miejscu, gdzie przedtem grały karabiny rosyjskie, rozległo się kilka salw austriackich. Około ósmej schodzę do szałasu i śpię na przemian w pozycji siedzącej w chałupie, to na grzbiecie jednego, to drugiego landszturmisty ${ }^{102}$ - same Rusini z Bukowiny, bardzo dobre chłopy, nie cierpią Magyarów ${ }^{103}$.

19/I, wtorek - rano posyłam po rozkazy, pułkownik każe mi przyjść naprzód, idę, tu ci strzały blisko, dum-dum po drzewach pryskają, zbieram jeszcze trochę maruderów. Przyłącza nas pułkownik do IV kompanii, pod komendą podp. Strzeleckiego ${ }^{104}$. Prowadzi nas młody, jak panna wyglądający porucznik od artylerii austriackiej. Szliśmy dobre dwie i 1 1 2 godziny, na końcu schodzimy po wąskim grzebieniu skalnym. Tu zaczynają świstać kule i tu spotykamy coś 36 landszturmistów z 11 legionistami (z II kompanii), mijamy ich,

Mołdawski w okręgu Suczawa). Jest to miejsce, gdzie nieformalnie zbiegają się granice Bukowiny, Siedmiogrodu (po rum. Transylwanii) oraz Marmarosz.

${ }^{98}$ Józef Rybak.

${ }^{99}$ Prawdopodobnie gen. Karol Trzaska-Durski.

${ }^{100}$ Moch - w gwarze wojskowej pejoratywne określenie Rosjanina.

${ }^{101}$ Moskal - dawna, historyczna (od 2. połowy XVII do początków XX w.) nazwa Rosjanina w języku polskim, uznawana za pejoratywną i pogardliwą.

${ }^{102}$ Landszturm (niem. Landsturm) - formacja wojskowa pospolitego ruszenia w armii austriackiej.

${ }^{103}$ Magyar - dawna, historyczna nazwa Węgra w języku polskim.

${ }^{104}$ Stanisław Strzelecki, ps. Jastrzębski (1885-1915), absolwent kolejowej Szkoły Technicznej Warszawsko-Wiedeńskiej Kolei Żelaznej, działacz PPS, aresztowany w czasie rewolucji 1905 r. i zesłany do guberni archangielskiej, skąd uciekł w 1906 r. i przedostał się do Lwowa, gdzie ukończył Wydział Budowy Maszyn Politechniki Lwowskiej. W czasie walk w Karpatach awansowany na porucznika piechoty, zginął 19 stycznia 1915 r. w bitwie pod Kirlibabą, pośmiertnie awansowany na kapitana i odznaczony Krzyżem Srebrnym Orderu Wojennego Virtuti Militari oraz Krzyżem Niepodległości. 
ja daję dyspozycje, aby 8 wysłać na prawe zabezpieczenie, a sam sunę tuż za kompanią. $\mathrm{Na}$ froncie otwarto ogień, jakkolwiek rozwinięcie linii tyralierskiej nastręczało ogromne trudności, nad nami dum-dum, na dobitek koło mnie zaczynają na prawo i lewo strzelać. Na próżno im tłumaczę, żeby zaprzestali ognia, na jakiś czas ustaje wszystko, posuwamy się dalej, a to Rosjanie tylko na chwilę udawali poddanie się, potem znowu strzelanina. Na dobitek wszystkiego zaczynają nad głowami pękać, jeden za drugim, szrapnele ${ }^{105} \mathrm{z}$ armatek legionowych (jak się później [s. 1468] okazało Moskale w czasie naszego ataku na Papfalvę ${ }^{106}$ otworzyli na naszych w dolinie taki ogień, że Januszajtis, pod którego komendą teraz jesteśmy, zmuszony był kazać prać artylerii na tę górę). Strzelecki prosi mnie, by mu przywołać sanitariuszy na front, bo ma dużo rannych. Idę, wracam z sanitariuszem, a tu już idą ranni, jeden za drugim, jeden miał ohydnie rozciętą twarz „od ucha do ucha” i to od kuli, zęby i język naruszony. Strzelanina na nowo się wzmaga, po jakimś czasie idzie cały pluton I-szy, wołam: stójcie, kto kazał wracać - oni mówią: Strzelecki zabity. Ktoś z tyłu krzyczy, że to porucznik nakazał odwrót, uspokajam, porządkuję, ale gdzie tam, dużo bractwa zwiało naprzód. Nareszcie nadchodzi porucznik, pytam się, czy jest zabezpieczenie, każe mi dać jakiego „tüchtigen Unteroffizier”107, już wyznaczam, a tu wpada Jaster ${ }^{108}$, że tam nie ma komu zasłaniać odwrotu, że 4 kompania rozbita, żebym ja zasłaniał, ostatecznie, żebym szedł naprzód, by się to wszystko w porządku cofało, a on już będzie osłaniał odwrót. Nagadawszy wiele, poszedł, biegnę ja naprzód, a tu już na jakie $600 \mathrm{x}$ od miejsca zbiórki tu i ówdzie kupka się kryje, nie licząc, że z każdym rannym poszło najmniej ze 3. Jednego plutonu z IV kompanii z kmdt. Smorawińskim ${ }^{109}$ brak. Ano obraliśmy sobie miejsce, rozpalamy pod drzewami ogniska, rozstawia się placówki i nocowanie, a porucznik od artylerii odchodząc, obiecał nam: Verpflegung und Munition zu verschaffen und möglichst noch der selben Nacht abzulösen ${ }^{110}$. Poznałem się z obecnym komendantem Jasterem i chorążym Kutą ${ }^{111}$, który ciągle śpiewał piosenkę: „Mańka, bo ci przerwę nogę - Mańka, Mańka, ja bez ciebie żyć nie mogę, Mańka...” Jeszcze przed bitwą dowiedziałem się, że Kaufer ${ }^{112}$ poszedł na urlop, a naszym komendantem jest Rybak ${ }^{113}$, podp. z baonu uzupełniającego.

20/I, środa - rano wyszukujemy jaką taką linię obronną, moi ją obsadzają, landszturm i reszta w obozie, patrol (Gumuła ${ }^{114} \mathrm{z}$ dwoma) doniosła, że na miejscu wczorajszej potyczki widziała 3 Moskali z bagnetami nasadzonemi. Naraz koło 10-tej kulki świstają, wybiegam

\footnotetext{
${ }^{105}$ Szrapnel - granat.

${ }^{106}$ Papfalva (rum. Fluturica), osada w północnej Rumunii w rejonie Kirlibaby.

${ }^{107}$ Tüchtigen Unteroffizier (niem.) - solidny (sumienny, porządny) podoficer.

${ }^{108}$ Stanisław Jaster, podporucznik, dowódca 4. kompanii po śmierci Stanisława Strzeleckiego.

${ }^{109}$ Mieczysław Smorawiński (1893-1940), od sierpnia 1914 r. w 2. Pułku Piechoty.

110 Verpflegung und Munition zu verschaffen und möglichst noch der selben Nacht abzulösen (niem.) - zapewnić zakwaterowanie i amunicję i możliwie jeszcze tej samej nocy [nas] zmienić.

${ }^{111}$ Kazimierz Kuta, chorąży, później podporucznik, dowódca plutonu.

112 Jan Kaufer, porucznik, dowódca batalionu.

113 Józef Rybak.

${ }^{114}$ Stanisław Gumuła, nauczyciel (ur. 1895 w Krzyszkowicach koło Wieliczki), podoficer 2. Pułku
} Piechoty, pod Kirlibabą dostał się do niewoli rosyjskiej, w której przebywał do 1918 r., co potwierdził 19 lipca 1927 r. w formie „Poświadczenia” T. Bierczyński, strona internetowa Towarzystwa Przyjaciół Grodna i Wilna Oddział we Wrocławiu, http:/grodnowilno.pl/gajczewska-ludmila (odczyt: 02.03.2020). 
w skok na pozycję, a tu landszturm i nasi wracają, krzyczę znowu: czego wracają, oni: Moskale tuż, tuż, ile ich nie wiedzą. Tymczasem komendant Jaster skądś z tyłu daje znać, cofnęli się, bo jak się pokazało, Moskale od samej góry obeszli nasze prawe zabezpieczenie i [s. 1469] bili w nasz niby obóz, wobec czego landszturm porwawszy konserwy, które właśnie dla nas nadeszły, zbiegł. Tu ranni Zamożny ${ }^{115}$ drugi raz (niedawno wrócił do kompanii po ranie pod Mołotkowem ${ }^{116}$ ) w niewoli i Parszywka K. ${ }^{117}$ ciężko i pięciu zaginionych: Gumuła, Piechowicz ${ }^{118}$, Bilski ${ }^{119}$, Golec i Zwinczak. Przeszliśmy dolinkę i nad nią się usadowiliśmy i tak do wieczora słuchaliśmy pukaniny, a raz nawet Jaster kazał pojedynczo strzelać, to znów 6-a kompania (ta nowa) strzelała nam ponad głowami. Wieczorem zeszliśmy spać do rowu przydrożnego, trochę choiny w zagłębieniu, ognisko, śnieg, ot i apartament zimowy do spania.

21/I, czwartek - wysypiamy się do ósmej, potem o dziewiątej godzinie zbiórka i siedzieć w pogotowiu przy ogniskach. Około drugiej naszej zaczyna się taki niemiłosierny koncert i austriackich, i legionowych armat, i mitraljez ${ }^{120}$, że niech ręka Boska broni. O drugiej zbiórka i ruszamy jako rezerwa baonu landszturmowego na Papfalvę gościńcem, ledwie biedna landszturma wyszła na widownię, a tu pu-pu-pu, wszystko wieje, dopiero major strzelił dwa razy, więc wszystko wróciło i strzela zawzięcie do góry, nie wiedząc kto, ani skąd do niego bije. I-szy baon obsadza górę na prawo, my leżymy na gościńcu w rezerwie, a później się posuwamy też za landszturmem, ledwie jedna kompania wydobyła się za zakręt, a tam zaczęli ją prażyć, na próżno nasz karabin maszynowy robił wiele poważnego hałasu. Landszturm musiał się cofnąć, dając kilku zabitych i kilkunastu rannych za parę minut, ściągło to bractwo, jakoś do nas nie strzelają, jeszcze potem puścili parę salw, ale niewinnych. Zeszli się grube ryby i radzą, i ja tam byłem, i wiele pyskowałem, bo miałem gust do gadania, stali my, stali aż ze dwie godziny, no i wróciliśmy na „kwatery”. Nasza kompania ma w nocy rezerwę pierwszej linii, major austriacki chciał nawet, byśmy stali u stóp góry, ale myśmy poszli do ognisk spać.

22/I, piatek - od rana trzęsie mnie febra, mimo to, że nas przekwaterowano do innych szałasów, ruszać mi się nie chce, ani jeść, a tu patrole wysłane do Kirli-baby ${ }^{121}$ skonstatowały, że tam Moskali nie ma, że Moskale w nocy na gwałt uciekli etc. I prowadzą jeńców, 8 naszych prowadzi 29 , ci niosą im karabiny, jakiś plutonowy utrzymuje porządek między nimi, tam jeden konny pędzi 12 itd. Sprowadzili koło 200 i wszystko chłopy jak się patrzy,

${ }^{115}$ Roman Zamożny.

${ }^{116}$ Bitwa pod Mołotkowem 29 listopada $1914 \mathrm{r}$.

${ }^{117}$ Konstanty Parszywka (1894-1915), student, poległ w czasie ataku na Papfalvę, spoczywa we wspólnej mogile obok kościoła rzymskokatolickiego we wsi Kirlibaba.

${ }^{118}$ Prawdopodobnie Marian Piechowicz (ur. 1899).

${ }^{119}$ W składzie Oddziału Stałych Drużyn Sokolich, który wyruszył 25 sierpnia 1914 r. z Wieliczki pod wodzą T. Bierczyńskiego, było dwóch braci Bilskich z Bieżanowa, Adam i Jan. W tym przypadku chodzi o Jana, robotnika kolejowego, żołnierza 2. Pułku Piechoty, Tomas z Wroński, Udział mieszkańców Bieżanowa w walce o niepodległość Polski (1914-1920), Kraków 2019, s. 22, 24, $27,67$.

${ }^{120}$ Mitraliez - karabin maszynowy.

${ }^{121}$ Kirlibaba (rum. Cârlibaba) - wieś w Rumunii w dolinie Złotej Bystrzycy w odległości ok. 25 km od przełęczy Prislop w paśmie Karpat Rodniawskich w południowej Bukowinie. Miała tu miejsce jedna z najcięższych bitew zimowych Brygady Karpackiej, która pokrzyżowała plany rosyjskie i zmusiła wroga do wycofania się na północ. 
wesoło witają nas i pozdra[s. 1470]wiają, ubrani wprost świetnie, mimo to wojna im się sprzykrzyła. Około trzeciej każą się zbierać, idziemy naprzód, ani to mnie ucieszyło, ledwiem się dźwignął i powlokłem się, kaszlę jak astmatyk, po $1 \mathrm{~km}$ ustaję i nocuję w domku.

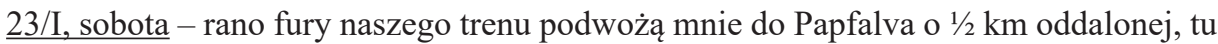
most i granica Bukowiny, mój komendant też szwankuje. Po południu poszli nasi do Kirlibaby, a ja czekam na furę i trzęsę się w febrze, ledwie mnie podwieźli pod most, schodzę i idę szukać tym razem na siedmiogrodzkiej ziemi, bo tu już Siedmiogród, w Ludwigsdor$f_{i}{ }^{122}$ naszych kwater. Idę niby paralityk, zachodzę na kwaterę, a tam cała kawaleria z Wąsowiczem ${ }^{123}$ na czele. Ledwiem się przywitał, rzuciłem się na łóżko i kaszlę bezustannie. Gdy oni odeszli, zażyłem jako niezawodny środek polecony mi przez dwóch lekarzy 1 gram aspiryny, no i guzik mi pomogło. Z nami kwateruje porucznik Zieliński ${ }^{124}$, były porucznik lejbgw. Anny Fiodorowicz ${ }^{125}$, który w czasie mobilizacji wziął urlop na trzy tygodnie, by się z rodziną pożegnać i tak dostał się do legionu. Stwierdza, że gdy widział pierwszych naszych w Królestwie i ich głupie wybryki, chciał wracać do pułku. Człowiek, któremu ani pobyt w junkierskiej szkole, ani lata służby w różnych miejscowościach koło Petersburga nie zdołały w nim zatrzeć Polaka.

24/I, niedziela - nie ruszam się, bo i tak kaszlę, piersi mnie szalenie bolą, mało jem, a tam nasi ciągle ściągają zmarzłe trupy naszych i Moskali, bo w górach pobojowiska się nie widzi, zwłaszcza w takich, dopiero potem. Wieś mało zniszczona, najwięcej ucierpiał kościół, który coś 10 razy czy tam więcej dostał granatem, a kulami karabinowemi podziurawiony jak rzeszoto, dziewuchy a nawet stare baby miały tu za swoje. Moskale zostawili nam kartki w niemieckim języku pisane, że nam zostawiają Kirli-babę, bobyśmy tam wszyscy zamarzli na tych górach, co wieczór mam lekką gorączkę.

25/I, poniedziałek - pogrzeb Strzeleckiego ${ }^{126}$, którego nasi ściągnęli z gór, przemawiał Durski i Januszajtis. Ja leżę cały dzień, por. Zieliński opowiada o swym pułku, o żołnierzach, manewrach, o tem, jak stali 4 miesiące w Peterhofie ${ }^{127}$ etc. Wieczorem [s. 1471] przy-

${ }^{122}$ Ludwigsdorf - niemiecka nazwa Kirlibaby.

${ }^{123}$ Zbigniew Dunin Wąsowicz (1882-1915), porucznik armii austro-węgierskiej, od sierpnia 1914 r. w Legionach, zginął 13 czerwca 1915 r., prowadząc szarżę polskiej kawalerii pod Rokitną.

${ }^{124}$ Prawdopodobnie Kazimierz Ziembiński-Zieliński, Nie tylko Pierwsza Brygada. Z legionami na bój, cz. 1, oprac. Stanisław Jan Rostworowski, Warszawa 1993, s. 270.

${ }^{125}$ Lejb-Gwardyjski Pułk Kirasjerów Jej Wysokości Imperatorki Marii Fiodorownej - pułk kawalerii sformowany w 1704 r., od 1796 patronką pułku była Maria Fiodorowna, żona cara Pawła I.

${ }^{126}$ Pogrzeb miał miejsce przy kościele we wsi Kirlibaba. Obecnie na niewielkim pomniku znajdują się dwie tablice: u góry pochodząca $\mathrm{z}$ okresu międzywojennego: „Tu spoczywają porucznik Legionów Polskich Stanisław Strzelecki i czterech legionistów polskich poległych bohaterską śmiercią pod Kirlibabą dnia 19 stycznia 1915 roku"; poniżej duża tablica, ufundowana w $2007 \mathrm{r}$. z napisami w języku polskim i rumuńskim: „Pamięci żołnierzy II Brygady Legionów Polskich poległych w dniach 19-23 stycznia 1915 roku w bitwie z oddziałami armii rosyjskiej, spoczywających w tej mogile: kapitan Stanisław Strzelecki, szeregowi: Józef Dzierża, Wilhelm Goll, Jan Grochowski, Józef Krzaśnik, Wojciech Matula, Jan Milewski, Konstanty Parszywka, Józef Pluta, Jan Skulak, Józef Tomasik, Michał Zaraza. Odnowiono z funduszy Senatu Rzeczypospolitej Polskiej staraniem Stowarzyszenia »Wspólnota Polska« i Towarzystwa Karpackiego. A.D. 2007”.

${ }^{127}$ Peterhof - miasto w północnej Rosji w rejonie Petersburga z pałacem cesarskim. 
padkowo do komendanta zaglądnął doktor, ale że ten poszedł grać w karty, zbadał mnie tak po wojskowemu i radził mi dwa proszki kodeiny, albo i 3-ci nad ranem, zresztą będziemy widzieć jutro.

26/I, wtorek - leżę, kompania idzie na patrole na Tatarkę i Klein-Kitkę ${ }^{128}$, ze starej kompanii wyszło 36, było 10, a do żołdu wieczorem zgłosiło się 60, taka wesoła kompania! Koniec końców nic nie zobaczyli, bo Moskale o $10 \mathrm{~km}$ w stronę Mołdawy ${ }^{129}$, a o kilkanaście km w stronę Jacobeny ${ }^{130}$.

27/I, środa - leżę, przez całą noc kaszel mnie morduje, że nie mogę sobie miejsca znaleźć, na dzień mi zawsze lepiej. Legionistom, którzy stoją na kwaterach urządzają rano ćwiczenia - ot, by się ruszali.

28/I, czwartek - rano leżę, ale ponieważ mi lepiej od południa wstaję. Pono jutro mają przyjść Niemcy, a niech przyjdą i Turki! Wieczorem nachodzi mnie dr Klimecki ${ }^{131}$, który ma huculską kompanię.

29/I, piatek - o 11-tej wymaszerowujemy w stronę Jacobeny, wszystko idzie naprzód, w nocy kwaterujemy o jakie $4 \mathrm{~km}$ od Kirli-baby. Co dzień mi lepiej, choć Garbusiński ${ }^{132}$ twierdzi, że źle wyglądam i powinienem wziąść urlop na jakie dwa tygodnie - Valestina ${ }^{133}$.

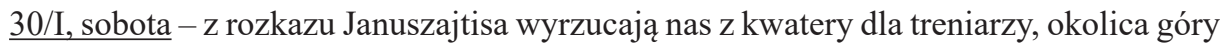
i góry, i dolina Złotej Bystrzycy ${ }^{134}$, w Lajosfalva ${ }^{135}$ nauczyłem się grać w pokera.

31/I, niedziela - rano o 4-tej pobudka, o 6-tej śniadanie, odmarsz rano, idą z nami 2 karabiny maszynowe, batalion Fischera (pułkownik Morton). Nasz pułkownik przyjechał wieczorem, doszliśmy do Eisenbergwerk ${ }^{136}$ i tu nocujemy w szałasach.

$\underline{1 / I I}$, poniedziałek - idziemy dalej i szukamy nieprzyjaciela, maszerujemy prawie cały dzień i dochodzimy do Briazy ${ }^{137}$, legiony dostają forpoczty, my idziemy nad wieś i tu na górze 4 placówki, pogotowie etc. Od dzisiaj ma komendę kompanii porucznik Pomazański ${ }^{138}$ $\mathrm{z}$ austriackiego wojska (30pp) .

2/II, wtorek - dostajemy rozkaz zajęcia Briazy i czekać tak długo, aż nadejdzie jakiś austriacki batalion. Wchodzimy ostrożnie, przeszukujemy chałupy, a tu patrzymy legioni-

\footnotetext{
${ }^{\text {a }}$ dopisane ołówkiem

${ }^{128}$ Tatarka, Mała Kitka (Klein Kitka) - wzgórza.

${ }^{129}$ Moldova-Sulița (Benia i Mołdowa) - miejscowość w Rumuni w okręgu Suczawa nad rzeką Mołdawą.

${ }^{130}$ Iacobeni (niem. Jakobeny) - miejscowość w Rumunii w okręgu Suczawa.

${ }^{131}$ Stanisław Klimecki.

${ }^{132}$ Prawdopodobnie Tadeusz Garbusiński (1891-1972), który wyruszył z Wieliczki pod dowództwem T. Bierczyńskiego, ANK, Naczelny Komitet Narodowy, sygn. 29/530/514, s. 661 (Sprawozdanie Powiatowego Komitetu Narodowego w Wieliczce z udziału powiatu wielickiego w odzyskaniu niepodległości w latach 1914-1917); Spis byłych żotnierzy Legionów Polskich ..., s. 34.

${ }^{133}$ Kopalnia żelaza w Valestinie.

${ }^{134}$ Bystrzyca Sołotwińska (Złota Bystrzyca) - rzeka na Ukrainie, dopływ Bystrzycy.

${ }^{135}$ Nagylajosfalva (Padina, Lajosfalva) - osada należąca do wsi Antalfalva w Serbii w południowej części Banatu.

${ }^{136}$ Eisenbergwerk (niem.) - kopalnia żelaza.

${ }^{137}$ Breaza (Briaza) - miasto w południowej Rumunii w okręgu Prahova.

${ }^{138}$ Henryk Pomazański.
} 
ści, stoi major Januszajtis i Haecker ${ }^{139}$ (III baon), którzy tu zeszli jeszcze wczoraj [s. 1472] o godzinie trzeciej po południu, a my głuptasy trzymaliśmy forpoczty. Po południu przychodzi 78 baon landszturmu, mamy iść. Ostatecznie decyduje się komendant wyjść wczas rano na drugi dzień. Komenderuje naszą grupą (centrum) pułkownik-brygadier Morton, brygada ma nr 72. W Briazie donoszą chłopi (z których zresztą 4 i 1 babę zastrzelono jako szpiegów), że od strony Sadowy ${ }^{140}$ ciągną 3 szwadrony Kozaków, a patrole są już o jakie 4 km. Placówki ma za nas baon Haeckera.

3/II, środa - o 4 wstajemy, o 6 wymaszerowujemy po ciemku ku Mołdawie. Po 1 1/2 godzinnym marszu stajemy na końcu przysiółka Briazy (po rumuńsku Breaza) i stajemy u stóp wzgórza poniżej komendy brygady, rozpalamy ogniska i czekamy na rozkazy - na Kokoszul wzdłuż gościńca (Januszajtis) i na Mołdowę Salizęę ${ }^{141}$ Fischer. Około 10 zaczęła artyleria (ros.) strzelać na wzgórze przed nami, a jeden granat uderzył w lasek brzozowy ponad domkiem brygady, nas cofnięto do domków, a około 12-tej dostajemy rozkaz wzmocnienia pozycji Fischera, dostajemy się na jego pozycje, a tam między dwoma domkami stały dwa nasze karabiny maszynowe i cały sztab. Moskale mają gdzieś być na wierzchołku góry i właśnie stamtąd strzelają do każdego, kto się na górze pokaże. Rano poszło 1/2 kompanii z por. Josem naprzód i doszli do chaty nad wąwozem, tu złapali 14 Mochów, lecz dalej iść nie mogli, bo z jednej strony strzelały Mochy, a na górze z prawej strony bił landszturm. Na szczęście karabiny maszynowe nie zrobiły nic złego, tylko landszturm z góry poraził 5 szeregowców i 1 Moskala w chacie (ciężko w nogę, kula została w kości), a por. Josego zraniono w nogę, w chwili gdy wywijał ku swoim białą chorągwią, żeby nie strzelali. Dostąpić do nich ani rusz, bo trzeba przejść z 500 x płaszczyzny, więc posłali pluton z prawej, by ostrzeliwał Mochów. Około 2-giej również landszturm na lewem skrzydle prosi o pomoc, bo ma tylko 30 ludzi, a chce na Mochów uderzyć. Poszedł komendant z I i II plutonem, przyszli tam, nie mogli zobaczyć obiecanych Moskali, natomiast na lewo zobaczyli większe siły. Porucznik landszturmu począł biadać, co tu robić, w końcu pono uciekł. Nasi przekonali się, że to Austriacy i nic. My, tj. III i IV pluton dostaliśmy rozkaz, skoro Moskale koło 4-tej przestali strzelać, pójścia po jeńców, ale zamiast odprowadzania [s. 1473] jeńców wysłaliśmy patrol na przeciwległe siodło do chaty, nic tam nie zobaczyli. A wieczorem poszedłem z 16-toma ludźmi na placówkę, z tego miałem wystawiać wedety ${ }^{142}$ i wysłać dwie patrole na wierzchołki, na prawo i lewo od siodła. O 12-tej zluzował mnie landszturm 35 i jeszcze się żalił, że ma mało ludzi.

4/II, czwartek - rano dostaliśmy rozkaz około 8-mej połączenia się z kompanią, a około 10-tej wymarszu do Mołdawy na kwatery. Tu kwaterujemy w rozburzonej chałupie, gdzie Kozacy z końmi kwaterowali. Minęliśmy pozycje artylerii rosyjskiej. Komendant zniecierpliwiony marudowaniem legionistów i brakiem karności zapowiada, że ma dość legionów, że wniesie podanie o wystąpienie z legionów. Ale może jakoś to będzie, że nie pójdzie, szkoda go, bo dobry chłop. Trochę ludzie fasowali i zjadłem rosół, od kilku dni, w ciągu których prawie się nic nie jadło, bo to człowiek nie ma gustu, a tylko w Briazie i na placówce mieliśmy mleka pod dostatkiem, tylko chleba nie ma.

\footnotetext{
${ }^{139}$ Henryk Haecker.

${ }^{140}$ Sadova - miejscowość w Rumunii w okręgu Suczawa.

${ }^{141}$ Moldova-Sulița.

${ }^{142}$ Wedeta - warta, straż.
} 


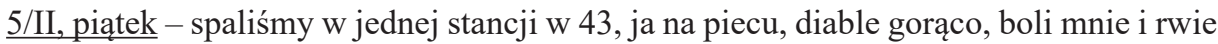
lewy bok, podobno mam Hexenschuss ${ }^{143}$, w każdym razie jestem słaby i nasz marsz z końca Mołdawy aż na początek Briazy (od Fundul Moldovi ${ }^{144}$ ) odbyłem z trudnością. Trwał on przeszło $2 \frac{1}{2}$ godziny, przyszliśmy po 12-tej, dosyć porządnie kwaterujemy, wypłata żołdu, wieczór trochę dostaliśmy specjałów.

6/II, sobota - od 7 1/2 do 9 1/2 ćwiczenia w mustrze, chłopcy porządnie robią. Obecnie należymy w ogóle do 13-go korpusu i idziemy jako rezerwa wojsk, które wczoraj w 4 rzutach wymaszerowały na Kimpolung. Tymczasem doniesiono koło 10-tej, że Kimpolung wzięte (podobno także Czerniowce ${ }^{145}$ ), wobec czego idziemy do Fundul Mołdawy, gdzie kwaterujemy. O już człowiek jest zmęczony, $12 \mathrm{~km}$, a już z trudem się maszeruje. Ciekawy wypadek miałem w plutonie, jeden odmroził sobie nogi, wobec czego gdyśmy pierwszy raz z Briazy wymaszerowali, zostawiliśmy go, aby go ten baon, który na nasze miejsce przyszedł, nim się zaopiekował. Lekarz mu przeciął palec i kazał mu sobie szukać swego szpitala, bo tu dla niego miejsca nie ma.

7/II, niedziela - rano rozkaz - wstecz zwrot i do Mołdawy, z początku myśleliśmy pewnie ofensywa na Kimpolung się skończyła, a to [s. 1474] tylko nasza dywizja przeznaczona została do marszu na Śniatyn ${ }^{146}$. Za Briazą odpoczynek 2-godzinny i jazda do Mołdawy, tu czekamy na kwaterę, wieczorem przeznaczyli nam dział, w którym nie było ani jednej chałupy. 1/2 śpi w domu, 1/2 w komorze, a 1 na polu, ja śpię na kanapie w poprzek, nogi spuściwszy na ziemię.

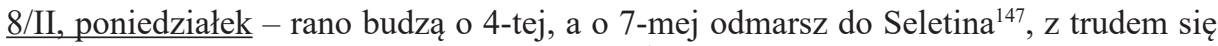
dowlokłem, nóg prawie nie czuję, mieszkamy u Żyda w eleganckim pokoju, a mamy maszerować na Berhomet ${ }^{148}$. Nieprzyjaciel w pełnym odwrocie i ścigają go grupy na Ujście Putilla $^{149}$-Wyżnicę ${ }^{150}$-Berhomet-Radowce ${ }^{151}$ i Góra Humora ${ }^{152}$, jednym słowem okropna ofensywa.

9/II, wtorek - rano do Russka, gdzie stał pułkownik z I baonem i masingwerem ${ }^{153}$, tu się dowiadujemy, że mamy iść do Schipoth ${ }^{154}$ prywatnego, maszerujemy znowu przez przeklęte serpentyny (my już mamy szczęście do tych serpentyn). Wleźliśmy w początek wsi, a tu do kwater jeszcze ze $2 \frac{1}{2} \mathrm{~km}$, rozkwaterowali nas, a tu za 3 kwadranse alarm i maszerujemy do Łopuszny ${ }^{155}$, która już pono zajęta. Podchodzimy z jakie $1 \frac{1}{2} \mathrm{~km}$, a tu na froncie się biją, a zbłąkane kule nad nami, postaliśmy sobie z godzinę, aż wreszcie poszliśmy na kwaterę.

\footnotetext{
${ }^{143}$ Hexenschuss (heksenszus) - postrzał, lumbago.

${ }^{144}$ Fundul Moldovi - wieś w Rumunii w okręgu Suczawa.

${ }^{145}$ Czerniowce - miasto w południowo-zachodniej części Ukrainy, historyczna stolica Bukowiny.

${ }^{146}$ Śniatyn - miasto na Ukrainie w obwodzie iwanofrankiwskim, położone nad Prutem.

${ }^{147}$ Seletin - miejscowość na Ukrainie w obwodzie czerniowieckim.

${ }^{148}$ Berhomet - miejscowość na Ukrainie w obwodzie czerniowieckim.

${ }^{149}$ Ust'-Putyla (niem. Uście Putilla) - miejscowość na Ukrainie na Bukowinie.

${ }^{150}$ Vyzhnytsya (pol. Wyżnica) - miejscowość na Ukrainie na Bukowinie.

${ }^{151}$ Radowce - miasto w Rumunii w okręgu Suczawa.

${ }^{152}$ Gura Humorului (Gurahomora, Gura Humora) - miejscowość w Rumunii w okręgu Suczawa.

${ }^{153}$ Masingwer - karabin maszynowy.

${ }^{154}$ Dolischnij Schepit (niem. Schipoth) - miejscowość na Ukrainie w obwodzie czerniowieckim.

${ }^{155}$ Łopuszna - wieś na Ukrainie w obwodzie iwanofrankiwskim.
} 
10/II, środa - budzą o 4-tej, o 5 1/2 wszystko ma być gotowe do odmarszu, zebrane na jednem miejscu, a o 10-tej wychodzimy. Mamy z rozkazu dywizji dotrzeć do Berhometu, tam się utrzymać, gdzie jutro ma nadejść cała dywizja. Ano se idziemy, podchodzimy do środka Łopuszny, a tu rosyjskie szrapnele zagradzają nam drogę, biją na przód, potem za nami, treffera ${ }^{156}$ nie było, ustawili nas z boku. Nareszcie nas Mochy z jakiejś górki zobaczyli i dalejże haratać do nas (eksplodujące), wiara w rowki, a ja im mówię: chodźcie do potoka, który miał obramowanie z drzewa i kamieni. Tu się bractwo zdekowało i tu zginął biedny chorąży Storożyński ${ }^{157}$, okazały i przystojny mężczyzna, miał diable szczęście do kart, wychylił się i dostał przez policzek w mózg. Oprócz tego dwóch raniło, między nimi i Korczaka ${ }^{158} \mathrm{z}$ mego plutonu w łopatkę, poszliśmy naprzód za chałupę, tu prali explosiv, nasz karabin maszynowy trochę się uspokoił, dość, że mogliśmy przejść do środka wsi i zadekować się za chałupy. Przy[s. 1475]szedł pułkownik i kazał iść doliną 11-tej kompanii, a my jako rezerwa przeszliśmy pod strzałami na przód wsi. Jeńców masami zbierają z gór i chałup, maszerujemy koło szóstej dalej, uszliśmy jakie 4 km, a tu mówią, że w domach na przodzie kwaterują Kozacy. Bestie zwiały przed nami przed kwadransem, po długich ceregielach idziemy na kwaterę.

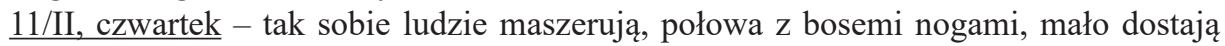
jeść, chleba prawie nie widzą, żeby nie ta kulesza ${ }^{159}$, to by z głodu zdechli. Jeszcze w naszej kompanii pół biedy, co można, to robią. O 7-mej zbiórka i przyłączeni do baonu Fabrycego ${ }^{160}$ maszerujemy naprzód, I i II pluton jako I linia, III i IV jako rezerwa, przed nami II/70 jako Nachrichten-Detachement ${ }^{161}$. Ta trochę puka, bo w Berhomecie było 20 Kozaków, rano bestie podpaliły dwór barona Wasilki ${ }^{162}$ i uciekły. Zajęliśmy nareszcie Berhomet, wysłali nas na górę Sołonec, tameśmy spatrolowali i pojedli sobie uczciwie mleka, jaj, masła etc. Ludzie krzyczą uradowani, częstują, czem mogą, klną na Moskali, jak wszędzie, żeby ich szlak trafił i opowiadają o krzywdach - zwykłe historie, tyle się już ich nasłuchało! A co za radość, a wszystko się dziwi, takie młode i Moskale sami mówią, że idą takie małe, ale dobrze biją, a drugi patrz, tacy mali, a takich niedźwiedzi pędzą. Ledwieśmy się roztasowali, zbiórka i marsz na jakieś tam wzgórze, gdzie ma być „Feind”163. Idziemy z góry wyrzuceni przez austriackiego majora na gościniec, tu się dowiadujemy, że Fabrycy na górze, idziemy tam, a tam nic nie ma, wracać na kwatery, tu znowu się spotykamy z Launhardtem ${ }^{164}$. Nagle nam mówią, że 6-te kompania zbiórka, klniemy, ale trudno - a to tylko trzeba było do placówek do słabej kompanii. Ale to jakbyśmy jeszcze z dzień maszerowali, to byśmy mieli

${ }^{156}$ Treffer (niem.) - celny strzał.

${ }^{157}$ Władysław Storożyński (ur. 1893), chorąży, student Politechniki.

${ }^{158}$ Wincenty Korczak, żołnierz 4. kompanii 2. Pułku Piechoty, ranny pod Papfalvą, Lista chorych, rannych, zabitych i zaginionych Legionistów..., s. 23.

${ }^{159}$ Kulesza - kleik z kaszki kukurydzianej lub mąki owsianej, wiejska potrawa znana w południowo-wschodniej Polsce i na Ukrainie.

${ }^{160}$ Kazimierz Fabrycy (1888-1958), od sierpnia 1914 r. w Legionach, dowódca kompanii w 1. Pułku Piechoty, dowódca batalionu w 2. i 3. Pułkach Piechoty.

${ }^{161}$ Nachrichten-Detachement (niem., fr.) - oddział informacyjny.

${ }^{162}$ Dobra Berhomet należały do mołdawskiej rodziny hrabiowskiej Wassilko de Serecki.

${ }^{163}$ Feind (niem.) - wróg.

${ }^{164}$ Alfred Launhardt. 
w kompanii ze 40 ludzi, to na patrol, to z jeńcami, to owo, a kompanię gonią z miejsca na miejsce, a ci, choćby szukali (Broń Boże!), to by jej nie znaleźli.

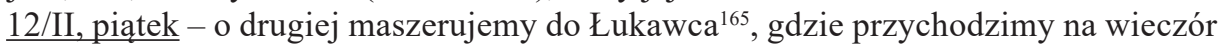
i z biedą wyszykujemy kwaterę.

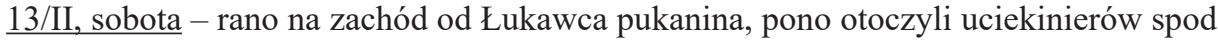
Wyżnicy i złapali coś ze 100, po połu[s. 1476]dniu zbiórka kompanii i batalionu, odczytano pochwałę 6-tej i 11-tej kompanii, a legioniści w ogóle zrównali się z najlepszemi wojskami austriackimi. Już przygotowałem sobie łóżko, a tu nasza kompania ma iść na placówki, wściekły sunę na te placówki, ale i tak dobrze spałem.

14/II, niedziela - po południu idziemy do Ober-Stanestie (Stanowce Wyżne), a z nami IV/3, III/2, II/3 i I/2, 2 oddziały karabinów maszynowych i bateria haubic polnych, podobno w Unter-Stanestie ${ }^{166}$ mają być Mochy.

15/II, poniedziałek - o 11-tej do Unter-Stanestie, miasteczko, kompania kwateruje w hotelu wcale porządnym. Moskale wczoraj mieli alarm i uciekli. Przed nami są dwa mosty - jeden na Czeremoszu ${ }^{167}$, drugi na Prucie i Moskale mają pono bronić przejścia albo zniszczą mosty. Zjechał do nas sztab nasz cały z trenem.

16/II, wtorek - drugi batalion nareszcie się z nami złączył, w południe wymaszerowujemy. Mój pluton idzie na placówkę na Róg, a Moskale są w Rewakoutz i Piedykoutz ${ }^{168}$, ale boją się obejścia. Reszta z pułkownikiem idzie na Karapcziu ${ }^{169}$ do Banilli ${ }^{170}$, bitwa tam była po południu, karabiny maszynowe $\mathrm{i}$ armaty - nad wieczorem zszedł do Waszkowiec ${ }^{171}$ pluton austriacki. Z Rogu widać Śniatyn i Zabłotów ${ }^{172}$. Wieczorem schodzę do drogi nad Wołyczanką, chłop do chałupy nie chce puścić, trzeba bagnet nasadzić, o $500 \mathrm{~m}$ ustawiam 4 ludzi na drodze.

17/II, środa - śnieg, w ogóle ociepla się, po południu nas luzują i na kwatery, mieszkam u staruszków Niemców, z wojną cicho.

$\underline{\text { 18/II, czwartek - kompania idzie do Kalinestie }}{ }^{173}$, gdzie do południa stoi w rezerwie forpoczt, a od południa idą dwa plutony na forpoczty, jeden do Waszkowiec bronić mostu, a drugi do Czartorii pilnować Zawala (jakieś siły kawaleryjskie rosyjskie miały tam być) $)^{a}$, dwa dni temu wzięto Kołomyję ${ }^{174}$, a dzień temu Czerniowce. Przebąkują, że w gazecie rosyjskiej znalezionej przez kawalerzystów była wiadomość o wzięciu Warszawy, coś dwa tygodnie temu słyszeliśmy, że zewnętrzne forty wzięte. I baon nasz stoi

a dopisane ołówkiem

${ }^{165}$ Łukawci (dawniej Łukawiec, Lukawetz) - wieś na Ukrainie w obwodzie czerniowieckim.

${ }^{166}$ Nyzhni Stanivitzi (niem. Unter-Stanestie, pol. Stanowce Wielkie) - miejscowość na Ukrainie na Bukowinie.

${ }^{167}$ Czeremosz - rzeka w zachodniej Ukrainie w Karpatach Wschodnich, prawy dopływ Prutu.

${ }^{168}$ Revakivci (Revakoutz) i Piedicăuți (Piedykoutz) - miejscowości na Ukrainie w obwodzie czerniowieckim.

${ }^{169}$ Karaptschiw (niem. Karapcziu) - miejscowość na Ukrainie w obwodzie czerniowieckim.

170 Banyliw (pol. Baniłów Ruski, Banilla Ruska) - wieś na Ukrainie w obwodzie czerniowieckim.

${ }^{171}$ Waszkowce (Waszkowiec) - miejscowości na Ukrainie w obwodzie czerniowieckim.

${ }^{172}$ Zabłotów - miejscowości na Ukrainie w obwodzie iwanofrankiwskim.

${ }^{173}$ Călinești (niem. Kalinestie) - miejscowość w Rumunii w okręgu Suczawa.

${ }^{174}$ Kołomyja - miasto na Ukrainie w obwodzie iwanofrankiwskim. 
w Banilli ruskiej, IV w Kniaziu i maszeruje na Orelec, z Czartorii meldowano, że widziano 4 armaty rosyjskie jadące ze Śniatyna na wschód.

19/II, piątek - obijamy się do południa, aż Excelencja ${ }^{175}$ [s. 1477] pojechał dowiedzieć się, co się dzieje i przekonał się, że Śniatyn wraz z okolicą wolny, dostaliśmy rozkaz maszerowania do Śniatyna. Idziemy na Berbestie, tu przeprawiamy się na 2 łódkach w miejscu, gdzie Czeremosz wpada do Prutu, a ponieważ przed nami przeprawiał się Fabrycy i juki, kompania sztabowa, więc dosyć to długo trwało. Skracaliśmy sobie czas popijaniem Ofensivgeistu i śpiewaniem chóralnem różnych obertasów. Już ciemno było jak dostaliśmy się na drugi brzeg i przez Piedykowce, Nepołukowce, Oroszeny do Śniatyna, gdzie dotarliśmy na kwaterę po godzinie 10 -tej.

$\underline{\text { 20/II, sobota }}$ - rano zawołał nas kapitan $\left(\text { Launhardt }{ }^{176}\right)^{\mathrm{a}}$ i zapowiedział różne rzeczy i że prawdopodobnie dłużej zostaniemy, pozwolono żołnierzom do 8-mej wieczorem chodzić po mieście i o 12-tej zrobili Marschbereitschaft ${ }^{177}$. Myśmy siedzieli w restauracji i dosyć porządnie się zabawiali, czekając do 31/2 rozkazu. O 4-tej wychodzimy do Stecowej, gdzie jest chryja z rozkwaterowaniem ludzi. Ludność niezwykle uprzejma, okolica zupełnie niezniszczona, jeść pod dostatkiem. W ogóle w Galicji stokroć lepiej niż na Węgrzech i innej Bukowinie, dostanie naszych wędlin, ciastek, wódek, likierów, win, pszennych bułek, ano jednem słowem wszystkiego. Gościńców pełno, tylko straszne zaspy, krajobraz się zmienił, bezdrzewne łagodne wzgórza czarnoziemu z gęstemi wioskami, dosyć bogatemi, pola i pola śniegowe, a na północy jar Dniestru - jabłek dobrych moc i czekolady!

$\underline{21 / I I, ~ n i e d z i e l a ~}-$ o 11 wymarsz do Horodenki ${ }^{178}$, tu ludność wita nas z muzyką, kokardki przeważnie czarno-żółte lub ruskie, mało polskich, brama tryumfalna z chorągiewkami, aż coś 9 polskich, portrety cesarza ubrane ${ }^{179}$. Hurra! Czołem! Ludzie się cieszą, przedtem u wejścia defilada przed Durskim, który zadowolony ze swych ludzi uśmiecha się, obecnie należymy do grupy dywizjonera gen. Lilienhofa ${ }^{180}$. Horodenka to miłe miasto jak Śniatyn, szczególnie jedzenie jak w domu, a tanio, dosyć dużo Polaków. Moskale tylko przechodzili $\mathrm{w}$ jedną przed paru miesiącami i obecnie w drugą stronę.

22/II, poniedziałek - wymarsz rano całej dywizji za[s. 1478]miast w stronę Harasy-

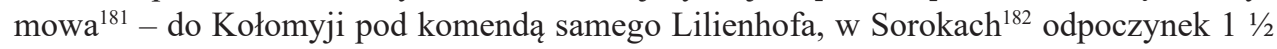
godziny, poczem do Gwoźdźca ${ }^{183}$ miasta, skąd wieczorem pociągiem do Kołomyji. Stanęliśmy w niej coś około 3-ciej, mimo odległości coś około $30 \mathrm{~km}$, jedziemy w wagonie

\footnotetext{
a dopisane ołówkiem

${ }^{175}$ Prawdopodobnie Karol Trzaska-Durski.

${ }^{176}$ Alfred Launhardt.

${ }^{177}$ Marschbereitschaft (niem.) - gotowość do wymarszu.

${ }^{178}$ Horodenka - miasto na Ukrainie w obwodzie iwanofrankiwskim.

${ }^{179}$ Franciszek Józef I Habsburg (1830-1916), od 1848 r. cesarz Austrii i król Węgier, Czech,

${ }^{180}$ Godwin Karl Alexander Arthur Paul von Lilienhoff und Adelstein (1862-1929) - komendant

24. brygady austro-węgierskiej 12. Dywizji Piechoty.

${ }^{181}$ Harasymów - wieś na Ukrainie w obwodzie iwanofrankiwskim.

${ }^{182}$ Soroki - wieś na Ukrainie w obwodzie iwanofrankiwskim.

${ }^{183}$ Gwoździec - miejscowość na Ukrainie w obwodzie iwanofrankiwskim.
} Chorwacji. 
„für 46 Mann”184, dosyć zresztą wygodnie, a jedziemy na Stanisławów ${ }^{185}$, gdzie Moskale wczoraj zajęli pozycje. Austriacy nad miastem, a dziś miał Wolf ${ }^{186}$ ponowić atak i zdobyć ją, w każdym razie idziemy dla sforsowania Halicza ${ }^{187}$, a jużeśmy myśleli, że zobaczymy Kołomyję, a tu nici.

Moskale śpiewają szereg piosenek:

na horidub

na dołynie kasza

Premyśla my nie dostały

Warszawa nie nasza

albo:

Awstrijcy i Prusaki czarnu kawu pijut

Ale za to dobre naszych bijut

itp.

23/II, wtorek - kobiety wszystkie ubrane w białe kożuchy i czerwone chustki, wyglądają jak maki na śniegu, wsie coraz porządniejsze, w każdej pełno domów murowanych. Jechaliśmy sobie coś aż do 11-tej i zajechaliśmy aż do Otynji ${ }^{188}$, skąd po dwugodzinnym staniu ruszyliśmy do Hryniewicz po prawdziwym galicyjskim błocie. Kląłem na Rusinów, że nie odgarnęli błota, koło 9-tej znaleźliśmy się na kwaterach.

24/II, środa - rano o 5 1/2 alarm, zbiera się bractwo jak na złość powoli, aż Lilienhof się złości: das ist ja ein Skandal ${ }^{189}$. Ostatecznie przed Tłumaczem ${ }^{190}$ oświadczył, że: „der Feind ist da" ${ }^{191}$. Tłumacz wcale duże i ładne miasteczko, śliczny Sokół ${ }^{192}$, nieuszkodzone, cóż, kiedyśmy przez nie tylko przeszli. Na ul. Słowackiego broń nabili (przyczem była okazja do strzelania) i ruszyli jako straż przednia całej jakiejś grupy, za nami zaraz karabin maszynowy, mitraliezy i inne baony, potem dopiero Austriacy z feldhaubicami, a Moskale mają być w Pałahiczach. Idziemy, a tu nic, doszliśmy do Olszowa, a ponieważ siła główna się urwała, stoimy. Ludzie ogromnie wszędzie [s. 1479] częstują, mleko, chleb, jaja wynoszą, jak zresztą wszędzie. Po dwunastej idziemy do Bratyszowa ${ }^{193}$, naprzód dwa patrole z naszej kompanii po 4 ludzi i podchorążowie, mój doszedł pod Niżniów ${ }^{194}$ i złapał 2 dragonów z końmi. Byli to z wiary muzułmanie, niezwykle mili, z naszą wiarą jakby ze starymi znajomymi rozmawiali. Doszliśmy pod dwór w Bratyszowie, gdzie już był Januszajtis i bił się z 600 dragonami i Kozakami, którzy byli nad Niżniowem w lasku. 7-ma kompania poszła gdzieś w lewo i biła salwy, karabin maszynowy im grzał i mitraljeza, a myśmy sobie stali

\footnotetext{
${ }^{184}$ Für 46 Mann (niem.) - dla 46 osób.

${ }^{185}$ Stanisławów (obecnie Iwano-Frankiwsk) - miasto w zachodniej Ukrainie, stolica obwodu iwanofrankiwskiego.

${ }^{186}$ Pułkownik Wolff.

${ }^{187}$ Halicz - miasto na Ukrainie w obwodzie iwanofrankiwskim.

${ }^{188}$ Otynia (Ottynia) - osiedle typu miejskiego na Ukrainie w obwodzie iwanofrankiwskim.

${ }^{189}$ Das ist ja ein Skandal (niem.) - to jest skandal.

${ }^{190}$ Tłumacz - miasto na Ukrainie w obwodzie iwanofrankiwskim.

${ }^{191}$ Der Feind ist da (niem.) - wróg tu jest.

${ }^{192}$ Budynek należący do Towarzystwa Gimnastycznego „Sokół”.

${ }^{193}$ Bratyszów - wieś na Ukrainie obwodzie iwanofrankiwskim.

${ }^{194}$ Niżniów - miejscowość na Ukrainie obwodzie iwanofrankiwskim.
} 
za szopą, a kule gwizdały sobie w górze. Jeden z naszej kompanii poszedł na stronę trochę na pole i kulka drasnęła go przy tej czynności w nogę, ten sam los spotkał sanitariuszkę z XI kompanii. W końcu artyleria austriacka rozciągła se drut telefoniczny i zaczęła bić na mosty, przez które przeprawiali się wieczorem Kozacy. 7-ma kompania zeszła do miasta i zaczęła do nich salwami na stojąco. Ogromny powstał rwetes i hałas, ale nam (7 kompania) zabili jednego ochotnika ze Śniatyna, który jeszcze w cywilu chodził i jednego ranili. Nad wieczorem puściła rosyjska artyleria już zza rzeki parę młodych szrapneli, a w nocy wysadzili oba mosty: kolejowy i drogowy, wieczorem umieszczono nas w stajni z krowami i końmi, a potem na kwatery.

25/II, czwartek - rano posłano 2 patrole, jedną miastem, a drugą na wschodnie wzgórza, zaś po jakimś czasie mnie na zachodnie ufortyfikowane (jak się później dowiedziałem przez Austriaków przez 4 lata, nie wolno nic fotografować, wskutek czego brak kartek korespondencyjnych, był komendant twierdzy, warty, każdego skauta lub wycieczkowca aresztowano, ogółem są dwa forty, jeden odkryty zupełnie, bardzo porządny, po którym się jacyś ludzie kręcili), zeszedłem na dół, przeszedłem przez Tłumaczek i tor kolejowy, tu nas ludziska przyjęli mlekiem, chlebem i jajami, zapraszali, żebyśmy zostali i prosili, byśmy wrócili przynajmniej na kwaterę. Przeszliśmy lasem i wydrapaliśmy się na te forty, skąd roztaczał się widok na Dniestr, mimo niepogody bardzo ładny, mosty oba długości na $500 \mathrm{~m}$ (w środku zerwane, drogowy się palił). Mosty zerwali Austriacy [s. 1480] w odwrocie, wyciągli armaty na forty, a wieczorem ściągli i uszli bez strzału, bo Zaleszczyki ${ }^{195}$ i Halicz ${ }^{196}$ były już wzięte. Po południu, gdyśmy się już w kazamatkach usadowili i zdążyli parę kołów wyrwać z ogrodzenia, aby zapalić w piecu, aż tu z góry zjechało sobie za Dniestrem około 40 Kozuniów ${ }^{197}$ czy huzarów i po jakimś czasie podsunęli się i zaczęli salwy, byli jednak za daleko. Wieczorem zeszedłem na dół, a Moskale zaczęli walić z armat więcej w most i pono sobie biła do 12-tej w nocy. My kwaterujemy u doktora nudziarza, który opowiada całe mnóstwo historyjek z mnóstwem szczegółów nic nas nie obchodzących, a co najważniejsze, powtarza jedną historyjkę w ciągu 2 godzin 3 razy.

26/II, piątek - od rana bije trochę artyleria rosyjska i salwy nasi, i oni tak sobie, nawet armatki wyciągli na forty i stamtąd strzelali, a na forteczkę przy moście wynieśli karabiny maszynowe i pukali, co prawda bez skutku, tak długo, aż nad wieczorem zaczęli do nich prać $\mathrm{z}$ armat i to tak celnie, że rozburzyli prawie całą forteczkę. Bractwo uciekło z komendantem karabinów maszynowych i doktorem, i adiutantem III baonu, a został na miejscu

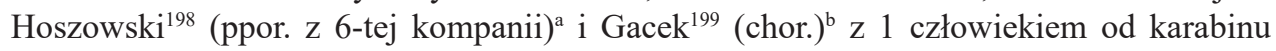
maszynowego i 3-ma z 11 kompanii i znieśli cudownym trafem nieuszkodzone karabiny i poczekali do wieczora, bo stamtąd do gościńca trzeba było biec po gołym polu i przynieśli je pod pachą. Patrol z 9-tej kompanii przyprowadziła z Ostrej (z 2-giej strony Dniestru)

\footnotetext{
a dopisane ołówkiem

${ }^{\mathrm{b}}$ dopisane olówkiem

${ }^{195}$ Zaleszczyki- miasto na Ukrainie w obwodzie tarnopolskim.

${ }^{196}$ Halicz - miasto na Ukrainie w obwodzie iwanofrankiwskim.

${ }^{197}$ Kozuń - żartobliwe określenie Kozaka.

198 Józef Hoszowski.

${ }^{199}$ Feliks Gacek (1893-1915), pochodził z Woli Filipowskiej koło Chrzanowa, student medycyny, zginął 6 marca 1915 r. w miejscowości Gruszka.
} 
2 huzarów, którzy oświadczyli, że w Koropcu ${ }^{200}$ jest tylko baon, 3 sotnie i 4 armaty, reszta uciekła do Buczacza ${ }^{201}$, reszta kompanii dostała się w ogień z 5 czy 6 stron, ale nikogo nie ranili nawet i wrócili koło 11-tej w nocy.

27/II, sobota - rano Rosjanie oddali 3 strzały armatnie, jeden granat trafił w chatę i zabił jedno dziecko, a 2 ranił. Z resztą cicho - miałem mieć inspekcję baonu, ale mię wysłali na placówkę do Kutysk ${ }^{202}$ i kazali mi iść nad Dniestrem, ale tamtędy iść nie było można, bo ścieżkę tuż pod skałą na przestrzeni 2 km Dniestr zatopił, więc musiałem wyjść na wzgórza i obchodzić jary. Dostałem się wreszcie na placówkę naprzeciw Ostra, która w 11 ludzi biła się coś z 80 Moskalami i wycofała się dopiero, gdy jej brakło naboi, ranili [s. 1481] 1 legionistę. Uzupełniłem ich 6 ludźmi, w Suchodole ${ }^{203}$ zostawiłem 9, a sam walę z 9 do Kutysk. Tu już dowiaduję się, że I pluton z Hoszowskim i obecny komendant kompanii Kaufer ${ }^{204}$, którzy wyszli o godzinę później, ale drogą i przyszli przede mną. Wobec czego wszystkie groźne rozkazy, które miałem wypełnić, spadły na inną głowę. Późno położyliśmy się spać w zrabowanym przez chłopów dworze.

28/II, niedziela - około 10 1⁄2 na placówkę do Łuh (Łuzoka), kilku domków naprzeciw Ostrej, Moskale strzelają od czasu do czasu, nasi rano trochę bili, w nocy cisza, czytam komedie Korzeniowskiego ${ }^{205}$.

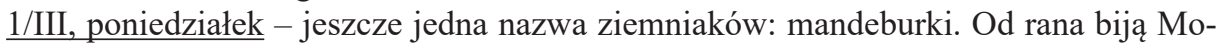
chy aż się to naszym uprzykrzyło, dali do nich kilkanaście strzałów i uciszyli się, z placówki w Suchodołach biją nasze mitraliezy, co ich już gruntownie uciszyło. Dostaliśmy fasunek $\mathrm{z}$ trudem dowieziony, a jeszcze więcej nam obiecali, kontynuuję Korzeniowskiego. Chłop jeden i Prządka ${ }^{206}$ z mojego plutonu w chłopskiem ubraniu przejechali na drugi brzeg i przywieźli 2 duże łódki już w nocy.

2/III, wtorek - rano śnieg, nic prawie nie widać. Przydzielili mi jedną mitraliezę, ale kazałem ją na górze zostawić. Dopiero po południu znaleźliśmy Moskali, posłałem do artylerii, by strzelała, armatka zjechała i dalejże, a Mochy fugas i pochowały się, wedetom w żaden sposób wytłumaczyć nie można, żeby nie strzelały - pono postrzelili w Ostrej babę w nogę i chłopa w palec u nogi. Ludność tu ładna, szczególnie mężatki i chłopcy, dziewczęta noszą oryginalne warkocze, z przodu białą zapaskę, z tyłu ciemno wiśniową, lajbik ${ }^{207}$ czerwony i buty (korale i kolczyki w kształcie serca). Ludność przychylna, wszystkiego od niej dowiedzieć się można o Mochach - pono w Koropiec stoi tylko 150 konnych, a do

\footnotetext{
${ }^{200}$ Koropiec - wieś na Ukrainie w obwodzie lwowskim.

${ }^{201}$ Buczacz - miasto na Ukrainie w obwodzie tarnopolskim.

${ }^{202}$ Kutyska - wieś na Ukrainie w obwodzie iwanofrankiwskim.

${ }^{203}$ Suchodół, Łuhy (Łuzoka), Ostra - wioski na Ukrainie w pobliżu Niżniowa nad Dniestrem, po obu jego stronach.

${ }^{204}$ Prawdopodobnie Jan Kaufer, Nie tylko Pierwsza Brygada. Z legionami na bój..., cz. 1, s. 283.

205 Józef Korzeniowski (1797-1863), poeta, powieściopisarz, nowelista i dramaturg, najznakomitszy (obok Aleksandra Fredry) komediopisarz epoki romantyzmu, przyczynił się do powstania tzw. „komedii charakterów”.

${ }^{206}$ Prawdopodobnie Władysław Prządka (ur. 1899), w czerwcu 1915 r. ranny na froncie w Basa-

${ }^{207}$ Lajbik - kamizelka bez rękawów.
} rabii. 
Ostrej i do Horyhlad chodzą patrole. Naród ogromnie ściśle obserwuje ${ }^{208}$ post, ma mnóstwo przesądów, zresztą oszczędny. W każdej prawie wsi dwór lub folwark, olbrzymie pola, dobra różnych hrabiów, książąt etc.

3/III - środa - po południu zmienia mnie drugi pluton na [s. 1482] placówce i kazuje mi iść na ochronę artylerii do folwarku górnego, stoi tam pluton armat (Magyary) i dziś od rana dali 91 strzałów, nie wiadomo do kogo, Haupttreffer ${ }^{209}$ to było rozbicie domku czerwonego, w którym rzekomo miało być kilkunastu Moskali. Wieczór zaszedłem do folwarku, kolacja elegancka, miła bardzo panienka, dość, że położyłem się o 11-tej.

$\underline{4 / I I I, ~ c z w a r t e k ~-~ o ~} 2$ obudzono mnie, że artyleria jedzie do Kubowiec, a ja jako „Geschützbedeckung”210 muszę z nim maszerować. Wziąłem i zebrałem się, a o 2 3/4 już byłem gotowy do wydania komendy: pluton marsz!, gdy nadjechał artylerzysta i zameldował, że: die Legionären bleiben hier, früh morgen werden się weitere Befehle bekommen ${ }^{211}$ - rozbierać się i spać. Rano rozkaz do Niżniów, treny (część), chorzy, wszystko wyjeżdża. Żydki pakują się na gwałt i wyjeżdżają, my czekamy na dywizjon kawalerii, który przyjeżdża z 4 karabinami maszynowymi i 2 armatami koło 1-szej, wobec czego my idziemy przez Tłumacz do Gruszka. Droga, zwłaszcza za Tłumaczem, wprost okropna, 2 pułki armat wyrywają, treny etc., a reszta naszych plutonów nie wiadomo gdzie, pono Rückzug ${ }^{212}$ na większą skalę.

5/III, piątek - od rana bije się placówka (11-ta i 9 kompania) z Mochami, na lewe skrzydło idzie 7-a i 8-a, o nas zapominają. Za jaką godzinę szalony ogień armatni, 7-a i 8-a wraca i cofa się przez wieś, idę i ja, przechodzimy w tyralierze na jedno wzgórze wstecz, stoimy tam z godzinę, nareszcie część naszych idzie nad Gruszkę, gdzie marzną, a my na placówki od strony Korolówka i cmentarza. Gdy z Korolówki K.T.D. ${ }^{213}$ chciała wyjechać na Tłumacz, Mochy obrzuciły wzgórze szrapnelami. Nad wieczorem rozkaz marszu na Tłumacz, idziemy se gościńcem i podziwiamy, jak nasza artyleria z Korolówki obrzuca elektrycznie oświetlony Tłumacz. Podchodzimy pod miasto i dowiadujemy się, że w nim już są nasi, ano dobrze, zakupujemy moc wina i śpimy w Sokole.

6/III, sobota - rano podpułkownik Fasser nas abfertiguje ${ }^{214}$ - placówki, my nie mamy żadnej służby, stąd uciecha, naraz dostajemy rozkaz wymarszu do Korolówki. Ledwie wyleźliśmy za miasto obrzucili nas z lekka karabinowymi strzałami, wyszliśmy dalej na wzgó[s. 1483]rze, a przed nami na drugiem wzgórzu stoi w grupkach dosyć dużych kawaleria (jak się później pokazało byli to Kozacy). Na drugim zaś wzgórzu w naszych oczach wyjechały zza lasu 4 armaty, ustawiły się, konie odprowadzono i zaczęły do nas prać, 3-ci szrapnel był u nas, dali ogółem ze 200 strzałów lub więcej. Artyleria nasza wyrywa wśród kolumny uciekającej po czystem polu za grupkę domów piechoty, tu zginęło paru, aż nareszcie dano rozkaz uciekania za górę. Ja z Launhardtem zostałem, a tu Kozacy na nas szar-

\footnotetext{
${ }^{208}$ W znaczeniu - przestrzega.

${ }^{209}$ Haupttreffer (niem.) - główna wygrana.

${ }^{210}$ Geschützbedeckung (niem.) - ochrona działa.

${ }^{211}$ Die Legionären bleiben hier, früh morgen werden sie weitere Befehle bekommen (niem.) Legioniści zostają tutaj, jutro rano dostaną dalsze rozkazy.

${ }^{212}$ Rückzug (niem.) - odwrót.

${ }^{213}$ KTD - Kavallerie-Truppen-Division (niem.) - dywizja kawalerii w wojsku austriackim.

${ }^{214}$ Abfertigen (niem.) - odprawiać, robić odprawę.
} 
żują. Launhardt krzyczy: chłopaki strzelać i sam strzela, a potem bierze coś 15 i odchodzi, mówiąc: strzelać, a potem wycofać się pojedynczo. Kozacy starają się to z tej, to z owej strony nas wziąść, więc my, nie chcąc się dostać do niewoli, wycofaliśmy się. Przedtem jeszcze zabrali Austriacy armatę, zostały dwa jaszczyki, a gdyśmy schodzili, chciała je nasza konnica zabrać, ale Mochy bili nad nie szrapnelami (pod wieczór je ściągnięto). Ja cofnąłem się do Gruszki (inni do Korolówki, gdzie pozostałe nasze 3 plutony obrzucono szrapnelami, 1 zabity, 7 rannych), tu znalazłem resztę baonu i poszliśmy na wzgórze 308, przed nami Korolówka i nasza linia, grzali ta do nas szrapnelami i tam, ale nieszkodliwie ${ }^{215}$. Wieczór nieścigani do Chocimierza ${ }^{216}$. + Felek G. (Gacek) ${ }^{217}$ zabity o 11 1/2 rano między chałupami, Nowak + ?

7/III, niedziela - rano poszukiwania za baonem, znaleźliśmy go za Bortnikami ${ }^{218}$ na folwarku przed Łysą Górą, stoi tu Lilienhof, co to było za gaudium ${ }^{219}$, gdyśmy się z resztą kompanii zeszli! Ucałowaliśmy się serdecznie z Józkiem (Hoszowskim)a i Tadkiem (Steckim) $)^{b}$. Stoimy na pogotowiu, armaty se biją, po południu coś pułk Kozaków od Korolówki walił, ale nasza artyleria dała im takiego szpryca (200 rannych i zabitych, jak jeńcy opowiadali), że się cofli w nocy. My służbę na Łysej G., noc w trupiarni (z zabitym przez przypadek Hucułem).

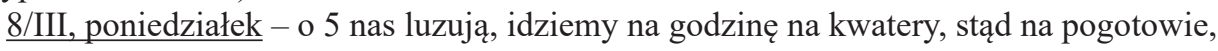
ludzie zaczynają na wielką skalę łazikować, artylerie się biją, od wieczora pozycje.

9/III, wtorek - śpimy od $1 \frac{1}{2} \mathrm{w}$ nocy do 6-tej na folwarku (w kuchni kwatera ofic.), wieczorem na pozycjec.

[s. 1493] [Prawdopodobnie 10/V, poniedziałek] ...mowano, placówki nasze się cofnęły, tylko bramki w drutach zapomnieli zamknąć, wreszcie je zamknięto, hukaliśmy pięknie $\mathrm{z}$ minenwerfera ${ }^{220}$ raz i drugi, i trzeci, i jak jeniec opowiadał moralne działanie (oprócz 2 rannych) było bajeczne. Jeniec powiada: strzelił i takoj kłoczok upał i niczewo - a tu naraz buchło jak 100 czortów, oficer, który był w krzakach krzyknął: Job twoju matj i wyrwał pierwszy, a za nim przez wąwóz żołnierze, honwedzi ${ }^{221}$. 8-a i 5-a kompania strzela, a my tylko sporadycznie i to salwami. Ja dałem 9 salw półplutonem, pierwsze 3 na wprost w las 10 set, drugie w lewo na 4sta i tam rzucono minę, a 3 ostatnie - na prawo w krzaczki na 6 set. Armatka nasza daje 8 kartaczów, a na kordonie 60. Karabin maszynowy grzmi naprzeciw 8-ej, oficer rosyjski krzyczy: po dwóch naprzód, rzepli mu miną i już nie poszedł

a dopisane ołówkiem

${ }^{\mathrm{b}}$ dopisane ołówkiem

${ }^{c}$ brak kilku kartek maszynopisu

${ }^{215}$ W czasie postoju w Bortnikach 15 marca 1915 r. Komenda Legionów,„...wyraziła pochwały i uznanie chorążym: Bierczyńskiemu Tadeuszowi i Steckiemu Tadeuszowi z II batalionu 2. pułku za wzorowe prowadzenie plutonów II batalionu 2. pułku oraz za okazaną zimną krew i orientację w bitwie pod Korolówką 6 marca b.r....", T. Malinowski, M. Szumański, 2. Pułk Piechoty Legionów Polskich..., s. 672.

${ }^{216}$ Chocimierz - wieś na Ukrainie w obwodzie iwanofrankiwskim.

${ }^{217}$ Feliks Gacek.

${ }^{218}$ Bortniki - wieś na Ukrainie w obwodzie iwanofrankiwskim.

${ }^{219}$ Gaudium (łac.) - radość.

${ }^{220}$ Minenwerfer (wyrzutnia min) - moździerz bliskiego zasięgu.

${ }^{221}$ Honvédség (pol. Honwedzi) - żołnierze wojsk węgierskich w XIX i XX w. 
nawet jeden naprzód, ale w 8-ej i u honwedów pękły minenwerfery, w 8-ej zraniło 2-ch, u honwedów nawet 5 , w tem 1 oberleutnanta ciężko, prócz 1 od karabinów maszynowych i 2 od artylerii naszej kulami. Moskale wyrwali, nawet nie zabrali trupów i jednego sanitariusza ciężko rannego w głowę, charczy i kona, list u niego znaleziono: „pozdrawia Cię pierwszy syn i drugi syn i trzeci syn i żona Cię pozdrawia”. Trupów znaleziono 6, pełno krwi w lesie, szarpi, podartych części ubrania, przybory, jeńców 7-miu, jeden Tatar ubrany w mundur legionisty poszedł na patrol, by poznajdować karabiny porzucone przez Rosjan, naturalnie Mannlichery ${ }^{222}$, zebrano ich przeszło 20. Tego dnia nad ranem zabrano w Toporowcach $^{223} 400$ jeńca, a Januszajtis 250 . Reszta dnia i noc cisza piękna.

$11 / \mathrm{V}$, wtorek - pogoda piękna, cisza, pono w Bałamutówce ${ }^{224}$ przełamano linię, „Geschützbedeckung”225 naszej polowej zwiało na koniach naszych armat i Kozunie zabrali armaty i trochę do niewoli. $Z$ początku mówili, że wszyscy oficerowie zabici lub w niewoli, potem się okazało, że są, a armaty miały odbić im 3 kompanie z 2-go pułku.

$12 / \mathrm{V}$, środa - koło południa Marschbereitschaft ${ }^{226}$, amunicję, której zabrać nie można, zniszczyć lub zakopać, telefon zwijają. Koło $2 \frac{1}{2} 2$ ruszamy lasem do Czerniawki ${ }^{227}$, zostaje tylko Faczyń (student z 7 gimn. z?) [s. 1494]ski 228 (4/XI 1915 w czasie kontrataku pod Optowoje ${ }^{229}$ kula potrzaskała mu lewe (?) ramię, bardzo odważny i spokojny - inteligentny) $)^{\mathrm{b}}$ (fotografia) ${ }^{\mathrm{c}}$ z 6 z mojego plutonu, którzy jeszcze godzinę mają zostać. Spalili obie budy oficerskie, szyby stłukli, a przed okopy postawiono manekina z kijem jako karabinem i zostawiono kartkę, aby byli nań łaskawi, jak go wezmą do niewoli. Ledwieśmy wleźli za wieś i dochodzili na pozycje, a tu we wsi już Kozacy i biją się z Romaniszynem ${ }^{230}$, my kładziemy się w rowie, później ja idę z plutonem rozwijać front koło kóp siana naprzeciw parku, podbiegamy wreszcie do przygotowanych okopów kilkanaście kroków od skraju lasu, który jest podrutowany, rowy bez kryć szrapnelowych, tu dajemy parę salw i idziemy spać.

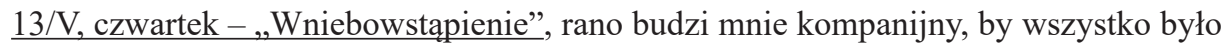
gotowe do odmarszu, ledwieśmy wstali, a tu z Czerniawki wyjeżdża sotnia Kozaków (może zresztą huzary), podałem celownik i czekać. Prawe ich zabezpieczenie pędzi ku nam pod las, ktoś wyrywa się ze strzałem, więc komenderuję: strzelać, 2 konie i 1 Kozaka ubito,

a dopisane ołówkiem, część nieczytelna

${ }^{\mathrm{b}}$ dopisane otówkiem

c dopisane ołówkiem

${ }_{222}$ Mannlicher M1895 - karabin powtarzalny, w czasie I wojny światowej przepisowy karabin armii austriackiej.

${ }^{223}$ Toporowce - wieś na Ukrainie w okolicy Czerniowiec.

${ }^{224}$ Bałamutówka - obecnie Bałamutiwka, wieś na Ukrainie w obwodzie chmielnickim.

${ }^{225}$ Geschützbedeckung (niem.) - ochrona działa.

${ }^{226}$ Marschbereitschaft (niem.) - gotowość do wymarszu.

${ }^{227}$ Czerniawka - wieś na Ukrainie w okolicy Czerniowiec.

${ }^{228}$ Prawdopodobnie plutonowy Stefan Faczyński, wymieniony jako ranny w: „Goniec Polowy Legionów. Dziennik Rozporządzeń Komendy Legionów Polskich” z 31 marca 1916, R. II, nr 14, s. 4.

${ }^{229}$ Optowa - miejscowość w rejonie Kostiuchnówki.

${ }^{230}$ Michał Romaniszyn, chorąży, mianowany porucznikiem dowodził 10. kompanią w walkach II Brygady na Wołyniu w 1916 r., kilkakrotnie ranny. 
jeden koń ranny, a jeden uciekł bez jeźdźca do Sadogóry ${ }^{231}$ i tam złapała go 5-ta kompania. Wszystko zwiało, a potem na pieszki podsuwają się rowem i strzelają przeważnie ekrazytówkami. Potem strzelamy do wyrywających Kozaków do Toporowiec, potem do przyjeżdżającej armaty (?) z jaszczykiem, która pod naszymi strzałami wyrywa za górę, ranią nam w tyłek sierżanta Laliczyńskiego ${ }^{232}$, odwrót lasem, jarami, niesie się na noszach rannego, a tu Moskale do nas strzelają w mniemaniu, że tam jesteśmy. Zbliżamy się do Sadogóry, a tu jakieś kolumny po polach się snują, jakieś tyraliery wyrywają, a przed nami armaty (ros.) a i biją „na lewo w skos”. Wchodzimy do Starej Zuczki²33, a szrapnele pękają nad Rohożną u wylotu Starej Zuczki. Łapie nas kilku Kozaków, wyrywam do budynku zniszczonego, nie ma nikogo, więc wyrywam za legionistami i tak aż do Nowej Zuczki, a tu od Rohożny już tyraliery, nareszcie jesteśmy za drutami. W Sadogórze wystarałem się o konie dla sierżanta. Co człowiek wody wypił, poczciwi ludziska płakali, przed każdym domem konwie z wodą, drogę pokazywali, byleśmy tylko uciec zdołali. Co chwilę odpoczywamy, idziemy przez Klokuczkę, Bilą (okopy wprost cacka na szczycie urwistych gór) nad Strylecki Kut na Serepy Hora, gdzie do[s. 1495]stajemy 2 bastiony, widok śliczny i niesłychanie przejrzysty, drogami na zachód maszeruje co najmniej brygada Rosjan, wchodzi do Szypenic ${ }^{b}$. 3-ci baon uważano za rozbity, ale jest, pono w drugim pułku znaczne straty, bo ten cofał się przed szrapnelami (pono Kaufer zabity, Klimecki w niewoli, ranny of. Korzeniowski ${ }^{234}$ ). Komendę nad nami od wczoraj ma Zieliński ${ }^{235}$, największa troska, jak tu treny dojadą, co będzie z jedzeniem dla ludzi, ja stoję tuż pod lasem na brzegu jaru.

14/V, piatek - w południe przeprowadzamy się bardziej na zachód, u stóp koty 309, w Prucie w czasie przeprawy potopiło się kilkunastu legionistów i trochę postrzelali huzarzy, pełno karabinów, amunicji, części mundurów naszych i rosyjskich przewożą na naszą stronę, nawet karabin maszynowy.

15/V, sobota - z rana 2 górskie (na zachód od nas), nasze małe 4 ( $\mathrm{z}$ tych 2 są w mym plutonie) i 2 polówki przepłoszyły 4 szwadrony Mochów usiłujących dostać się do Mamajowiec ${ }^{236}$, ale też wyrywali! A widoczni są jak na dłoni gołym okiem na jakie $7-8 \mathrm{~km}$. Potem strzelali do stada baranów (3 czy 4 ubili), potem do 2 koni osiodłanych, a pod wieczór rozprószyli jakiś pluton konnicy. Jak te pieniądze lecą... Wojska nasze zajęły już linię Borysław $^{237}$, Stary Sambor ${ }^{238}$, Dobromil ${ }^{239}$, Przeworsk ${ }^{240}$, Niemcy zajęli Tylżę ${ }^{241}$.

a dopisane ołówkiem

${ }^{\mathrm{b}}$ ołówkiem poprawione na: Szybenic

${ }^{231}$ Sadogóra (Sadagóra) - miasto na Ukrainie, obecnie dzielnica Czerniowiec nad Prutem.

${ }^{232}$ Bronisław Laliczyński.

${ }^{233}$ Stara Zuczka i Nowa Zuczka - wsie, obecnie dzielnice Czerniowiec.

${ }^{234}$ Prawdopodobnie Romuald Korzeniowski, chorąży, ranny po raz drugi, po raz pierwszy 22 grudnia 1914 r. w miejscowości Kliva, przebywał przez pewien czas na rekonwalescencji w Wiedniu, Lista chorych, rannych, zabitych i zaginionych Legionistów..., s. 24.

${ }^{235}$ Pułkownik Zygmunt Zieliński.

${ }^{236}$ Mamajowce - wieś na Ukrainie w obwodzie czerniowieckim.

${ }^{237}$ Borysław - miasto na Ukrainie w obwodzie lwowskim.

${ }^{238}$ Stary Sambor (dawniej Staremiasto) - miasto na Ukrainie w obwodzie lwowskim.

${ }^{239}$ Dobromil - miasto na Ukrainie w obwodzie lwowskim.

${ }^{240}$ Przeworsk - miasto w województwie podkarpackim.

${ }^{241}$ Sowieck (Tylża) - miasto w Rosji w obwodzie kaliningradzkim. 


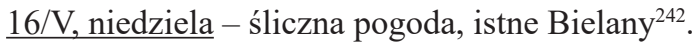

$17 / \mathrm{V}$, poniedziałek - linia nasza biegnie przez Leżajsk ${ }^{243}$, Rudnik ${ }^{244}$, Jarosław ${ }^{245}$, Sambor $^{246}$. O ofensywie rosyjskiej na nas mówi major Morath w N.(eue) Fr.(eie) Pr.(esse) ${ }^{247}$, jako o Kopflosigkeit ${ }^{248}$.

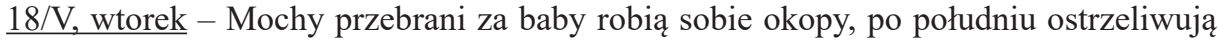
nasze armatki szkołę. Nasi są pono w Szybenicu, wieczorem rozkaz wyszukania najkrótszej drogi do JH (Jägerhaus $\left.{ }^{249}\right)^{a}$ spalonego, gdzie stoją treny, śliczny stamtąd widok, akurat z Mörsera ${ }^{250}$ biją na Moszków, co za wybuchy. W nocy armatki spakowaną mają amunicję, tylko one stoją. Zabierają Tadka S.(teckiego) do 5 kompanii.

$19 / \mathrm{V}$, środa - cisza, pogoda, zaczynają się upały, wieczorem pali się kilka domów w Stecowej (?), pono Mochy miały pod Kołomyją duże straty. Wieczorem depesza - Sieniawa ${ }^{251}$ zdobyta. [s. 1496] Ataki rosyjskie na płn.-zach. aż po Lubaczówkę ${ }^{252}$ odparte i tutaj przekroczono San, na płn. od Sambora zdobyto kilka miejscowości. Walki koło Stryja i za Kielcami trwają dalej, zresztą nic.

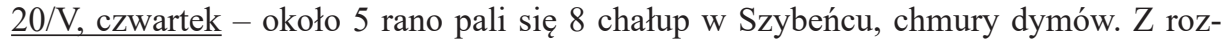
kazem pułkowym dostaliśmy: ja, Maciuś $\left(\text { Bartel }^{253}\right)^{\mathrm{b}}$ i 2 Tadki (Parafiński ${ }^{254}$ i) ${ }^{\mathrm{c}}$ po 3 dni aresztu okopowego za oponowanie rozkazowi przeniesienia chor. Steckiego do 5 kompanii. A myśmy byli w raporcie z prośbą, o ile to możliwe, zatrzymania go w naszej kompanii. Po odsiedzeniu kary wolno nam apelować, ano dobrze, inspekcja baonu - pierwszy raz widziałem dokładnie jednopłaszczyznowiec ${ }^{255}$ rosyjski, białe koło z niebieską obwódką.

21/V, piatek - od rana biją koło Czerniowiec dziwnie ciężkie armaty, w południe burza, w Szerowcach Górnych pali się jakiś folwark. Nasi maszerują na Rudki ${ }^{256}$, stamtąd

a dopisane ołówkiem

${ }^{\mathrm{b}}$ dopisane ołówkiem

'dopisane otówkiem

${ }^{242}$ Bielany - wieś pod Krakowem z klasztorem Kamedułów, w którym w dzień Zielonych Świątek odbywał się odpust gromadzący tłumy Krakowian i okolicznych mieszkańców na majówce.

${ }^{243}$ Leżajsk - miasto w północnej części województwa podkarpackiego.

${ }^{244}$ Rudnik nad Sanem (dawniej Rudnik) - miasto w województwie podkarpackim w powiecie niżańskim.

${ }^{245}$ Jarosław - miasto w województwie podkarpackim.

${ }^{246}$ Sambor - miasto na Ukrainie w obwodzie lwowskim.

${ }^{247}$ „Neue Freie Presse” - dziennik austriacki wydawany w 1. 1864-1939 w Wiedniu.

${ }^{248}$ Kopflosigkeit (niem.) - roztargnienie, panika.

${ }^{249}$ Jägerhaus (niem.) - domek myśliwski.

${ }^{250}$ Mörser 16 - ciężka haubica.

${ }^{251}$ Sieniawa - miasto w województwie podkarpackim w powiecie przeworskim.

${ }^{252}$ Lubaczówka - rzeka w Kotlinie Sandomierskiej, prawy dopływ Sanu.

${ }^{253}$ Maciej Euzebiusz Bardel (ur. 1895), chorąży, później porucznik Legionów Polskich, dowódca 7. kompanii 3. Pułku Piechoty, w której dowódcą plutonu był T. Bierczyński, Marian Porwit, Spojrzenia poprzez moje życie, Warszawa 1986, s. 123.

${ }^{254}$ Tadeusz Piotr Parafiński (ur. 1896 w Krakowie).

${ }^{255}$ Jednopłaszczyznowiec - samolot jednopłatowy. Znakiem Imperatorskich Sił Powietrznych Rosji było białe koło z czerwono-niebieską obwódką.

${ }^{256}$ Rudki - miasto na Ukrainie w obwodzie lwowskim. 
do Lwowa, gdyby się im udało, to by znowu może złapali armię rosyjską z pod Drohobycza $^{257}$. Przemyśl ma być prawie otoczony, Niemiaszki cofnęły się na wschodnim brzegu kanału Ysery ${ }^{258}$, poczta nasza jest aż w Czudemie, wskutek tego połączenie nasze ze światem prawie przerwane, robi się chłodno, całe przed północą burze wokoło, pioruny aż oślepiają.

22/V, sobota - deszcz pokrapuje, zamglone, z Włochami kiepsko, 407 głosów w parlamencie za, 74 przeciw pełnomocnictwom rządowi w razie wojny, ale żeby te kogucie pióra dostały porządnie w skórę, podły naród, teraz się wybrali z wojną ${ }^{259}$. Jeńców od 2 maja jest 194 tyś., - 128 armat i 368 karabinów maszynowych, a co musi być amunicji i innych rzeczy! O dziwo! na noc Moskale nie zapowiedzieli ,angriffu”260, bardzo dawno jak tego nie zrobili, wobec czego nie zaostrzono pogotowia i nie podwojono czujności. Swoją drogą co dzień podwajają czujność, wobec czego dziś musiałaby być czujność kilka milionów bilionów razy większa niż np. przed 2 miesiącami. Ciekawym, czemby się tak zwielokrotniona czujność objawiała? W ogóle nie jesteśmy na kwaterach, to jesteśmy w pogotowiu marszowym, a na pozycji w ostrem pogotowiu. Jednem słowem staniemy się wkrótce jakimś idealnem pogotowiem.

23/V, niedziela, Zielone Świątki - prawie że jesteśmy na [s. 1497] Bielanach, nawet deszcz i chłód je przypomina. Moi, rewanżując się, kupili bekę piwa, wódkę, kiełbasę etc., przystroili i ubrali „altanę” (dla rezerwy) i zaprosili na małą popijawę. Przyszedł Maciuś261 i tak zabawiliśmy się parę godzin. Po południu deszcz jeszcze większy. Moskale na serio zapowiedzieli ataki (na Januszajtisa), wobec czego sprowadzono huzarów i okropnie zaostrzono pogotowie, podwojono placówki, jednak atak z powodu niepogody się nie odbył. Areszt się mi skończył, do jutra mają karabiny maszynowe M7, które są jeszcze w Legionach, być wymienione na M 7/12 262, a to z powodu wyjazdu, jak brzmiała depesza brygady. Jak wojna z Włochami wybuchnie, to i nie ma co marzyć, byśmy stąd szli do Królestwa.

24/V, poniedziałek - pogoda, chłodno, stajemy do raportu po odsiedzeniu kary z zażaleniem na komendę baonu i prosimy o raport w pułku. Maciuś ma tam jutro stanąć. Pod wieczór widać w odległości około $8 \mathrm{~km}$ przesuwający się szczytem wzgórz baon rosyjski lub 5 kompanię z Witelówki do Szubrańca ${ }^{263}$.

25/V, wtorek - dtto, depesza o pojmaniu 6300 Włochów i 30 oficerów. Komendant grupy, nawet pułkownik Zieliński. Legioniści stają się coraz lepszymi żołnierzami, relutoństwo $^{264}$ zanika powoli. Kołomyja w ogóle dużo wpłynęła, szkoda, że tak krótkośmy byli,

${ }^{257}$ Drohobycz - miasto na Ukrainie w obwodzie lwowskim.

${ }^{258}$ Yser - rzeka w północnej Francji i zachodniej Belgii.

${ }^{259}$ Włochy dołączyły do Ententy (porozumienie Wielkiej Brytanii, Francji i Rosji) 23 maja $1915 \mathrm{r}$.

${ }^{260}$ Angriff (niem.) - szturm.

${ }^{261}$ Maciej Euzebiusz Bardel.

${ }^{262}$ Schwarzlose M.7/12 - ciężki karabin maszynowy w armii austriackiej.

${ }^{263}$ Șubrănești (ukr. Șubraneț, niem. Schubranetz) - wieś na Ukrainie w obwodzie czerniowieckim.

${ }^{264}$ Reluton (od łac. Relutum) - żołd, pieniężny ekwiwalent kosztów całodziennego wyżywienia. 
zresztą warunki atmosferyczne sprzyjają, toteż chłopcy się trzymają, o chorobach prawie nie słychać, w ogóle zżyli się z wojną, już ich nie ciągnie ani do domu, ani do szpitala - ot, tak my wszyscy. Wszystko mi jedno, to moje oblubienie - czy wojna trwać będzie rok, czy pół, czy będzie jeszcze jedna wojna, czy dwie - w ogóle staję się naprawdę wojakiem! fachowcem, już się człowiek na niejednem rozumie gruntownie, nabyło się koniecznego spokoju, człek stał się na pół zwierzęciem - myśliwym. Z satysfakcją widzi się treffery, których ofiarą jest przecież życie człowieka lub konia. Do niewoli legionista da się złapać, jak już jest fizycznie wyczerpany, zresztą wyrywa pięknie, jak trzeba - rekwiruje fury, albo gdy mu się to uda, przebiera się szybko w cywila i wraca do swoich. Ludność tu przyjazna, w obu Zuczkach i Czerniowcach dużo Polaków, będzie ich tu ze 20 000, tak bractwo płakało, jakeśmy się cofali. [s. 1498] Co do Kaufera prawda - w najlepszym razie czeka go zwolnienie z Legionów, stracił 180 ludzi, na cały baon 450 - ładna historia. To nie Włochów, to Mochów pod Kielcami tyle złapano, ogólna cyfra od 2-go maja - 200000. U legionistów car nazywa się nasz król - pozycje całe patrolami i placówkami, to pilnowanie, żeby Moskale drutu nie zwinęli i żeby nim nie odrutowali swych pozycji. W Istrii pokazała się konnica włoska, na granicy Tyrolu walki wojsk pogranicznych, w Genui 19 pułków, a w Modenie wojska francuskie, ale co tam o to. Mam w plutonie Admusa z Mesnej ${ }^{265}$, istny głupi Maciuś, a dobry chłopak, nabierają go Johaśką, która mu miała porodzić śledzia, piszą do niego na ten temat kartki. Hasła, względnie odzewu nauczyli go w ten sposób, że zamiast „Sarajewo”, powiedzieli mu s... na lewo, kiedyś znowu haltuje 2 landszturmistów i pyta o hasło, ci nie wiedzieli, co to znaczy hasło, a on: nie wicie, to chodźcie bliżej, to wam powiem.

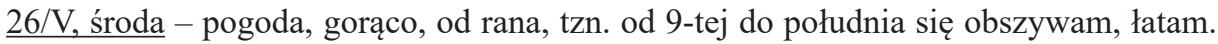
Rozkazem brygady dostała piechota 3 pułku pochwałę za sprawne wycofanie się z pozycji naddniestrzańskich, co do Kaufera, stwierdzono oddanie pod sąd bez wymieniania nazwiska. Adamus nazywa przewód elektryczny - sznurkiem elektrycznym, co to światło ciągnie. Po południu nasz aeroplan ostrzeliwały Mochy z Laszówki czy Kocmania ${ }^{266}$ szrapnelami. Obserwujemy słońce, jedną większą, a drugą malutką plamę, tylko protuberancji ${ }^{267}$ nie można zobaczyć, tarcza słoneczna na kraju jest pogryziona i ma wzgórki.

27/V, czwartek - przedwczoraj nasi wzięli Radymno ${ }^{268}, 21$ tysięcy Mochów, 40 karabinów maszynowych i 37 armat - za to ponoć Mochy w Nadwórny ${ }^{269}$. Ale znowu jak pierwszy raz Mörsery strzelały, to rozbiły 4 zajeżdżające na pozycje armaty doszczętnie, jak zeznali wzięci do niewoli artylerzyści. Wieczorem dowiadujemy się, że wzięto przyczółek mostowy Zarudy, a za oba te dni ogółem 54 lekkich, 10 ciężkich armat, przeszło 40 karabinów maszynowych, 25 tysięcy jeńca i 14 wozów amunicji. Na wszystkich frontach idzie dobrze, nawet Niemcy ofensywę robią pod Ypern ${ }^{270}$, pochłaniam dziesiątki gazet.

${ }^{265}$ Michał Adamus (ur. 1893 w miejscowości Meszna koło Bielska-Białej, poległ 5 listopada 1915 r. pod Wielką Miedwieżą).

${ }^{266}$ Kocman - miasto na Ukrainie w obwodzie czerniowieckim na Bukowinie.

${ }^{267}$ Protuberancje (łac.) - wyskoki słoneczne.

${ }^{268}$ Radymno - miasto w województwie podkarpackim w powiecie jarosławskim.

${ }^{269}$ Nadwórna - miasto na Ukrainie w obwodzie iwanofrankiwskim.

${ }^{270}$ Ypres - miasto w Belgii w regionie Flandrii. W trakcie tzw. drugiej bitwy pod Ypres (22 kwietnia - 25 maja 1915 r.) armia niemiecka użyła broni chemicznej. 
[s. 1499] Zgęszczają nam pozycje, bo na miejsce I baonu przychodzi 1 baon austriacki. Na Czerniowce znowu rzucono 2 bomby. Serbia niezadowolona z Włoch, a Hiszpania rusza się kuli onemu lądowaniu wojsk angielskich w Portugalii.

29/V, sobota - w wąwozie wytyczamy okop i zaczynamy (podług mego planu), inspekcja baonu, po południu zabieramy się do roboty niżej, na skraju wąwozu.

$\underline{30 / V}$, niedziela - roboty dalej, wieczorem awantura ze Świetlikiem ${ }^{271}$ o placówkę, pouczenie $\mathrm{z}$ baonu jak się spełnia służbę, a nazajutrz pod adresem wszystkich komendantów plutonów, by sobie przeczytali regulamin, odpowiedzialnymi się czyni komendantów plutonów, komendanta kompanii, naturalnie wszystko pod adresem 7-mej kompanii. Zdaje się, że tu wcale nie chodzi o pełnienie służby, tylko o szukanie dziury w całem - wstrętna biurokracka pedanteria. Dotychczas nie mogłem jej zaobserwować w Legionach: wir sind mehr militärisch und reglamentärisch, als Militär und Reglament selbst ${ }^{272}$ - ale no trudno, wdepnęło się. Dotychczas uważałem za istotny cel unseres Feldzuges ${ }^{273}$ wojnę z Moskalami, a dzisiaj pełnienie służby według regulaminu. Co dzień koło południa burza.

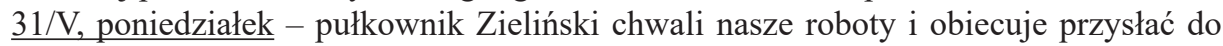
nas hr. Morsztyna ${ }^{274} \mathrm{z}$ N.K.N. ${ }^{275}$, by się przypatrzył pracy legionistów. Wczoraj z poczty dowiedziałem się o śmierci Antka ${ }^{276}$ pod Bieczem w dniu 4/V b.r., całe szczęście, że dostał w głowę i przytomności do śmierci nie odzyskał. No dotąd zabiły te psiekrwie mi brata ciotecznego Kazka ${ }^{277}$, Felka G. ${ }^{278}$

\footnotetext{
${ }^{271}$ Prawdopodobnie Stefan Świetlik, Nie tylko Pierwsza Brygada. Z legionami na bój..., cz. 1, s. 303.

${ }^{272}$ Wir sind mehr militärisch und reglamentärish, als Militär und Reglament selbst (niem.) - jesteśmy bardziej wojskowi i przepisowi (regulaminowi) niż samo wojsko i regulamin.

${ }^{273}$ Unseres Feldzuges (niem.) - naszej kampanii (wyprawy).

${ }^{274}$ Hrabia Ludwik Hieronim Morstin (Morsztyn) (1886-1966), poeta, brał udział w pracach Naczelnego Komitetu Narodowego.

${ }^{275}$ NKN - Naczelny Komitet Narodowy powołany w Krakowie 16 sierpnia 1914 r. jako władza wojskowa, polityczna i skarbowa dla Galicji, zainicjował utworzenie Legionów Polskich u boku armii austriackiej.

${ }^{276}$ Antoni Kazimierz Mikuła (1891-1915).

${ }^{277}$ Kazimierz Heyda (1894-1915), syn Zygmunta (brata Wandy, matki T. Bierczyńskiego), absolwent renomowanego prywatnego gimnazjum - Zakładu Naukowo-Wychowawczego Ojców Jezuitów w Chyrowie, chorąży Legionów, zginął podczas patrolu 14 lutego 1915 r. w rejonie Nadwórnej, prawdopodobnie koło miejscowości Porohy. Legionistą prawdopodobnie był także drugi Kazimierz Heyda, syn Karola (brat Wandy i Zygmunta), ur. w 1895 r., który według notatki sporządzonej przez T. Bierczyńskiego zginął 14 października 1914 r. w patrolu koło Nadwórnej. W Legionach walczyli także dwaj synowie Teresy Heydzianki - Włodzimierz (1895-1955) i Eugeniusz (1896-1971) Gaczołowie.

${ }^{278}$ Feliks Gacek.
} 


\section{BIBLIOGRAFIA}

\section{Źródła rękopiśmienne}

Archiwum Narodowe w Krakowie

Akta Miasta Krakowa, sygn. 29/33/6.11/Osob.1723.

Akta stanu cywilnego Parafii Rzymskokatolickiej w Bolechowicach, sygn. 29/337/59.

C.K. Seminarium Nauczycielskie Męskie w Krakowie, sygn. 29/489/79-80.

Gimnazjum i Liceum św. Jacka w Krakowie, sygn. 29/487/15-16.

Organizacje społeczne - zbiór szczątków zespołów, sygn. 29/575/24-26.

Spis ludności miasta Krakowa z r. 1870, sygn. 29/86/8.

Spis ludności miasta Krakowa z r. 1880, sygn. 29/87/14.

Zbiory prywatne Andrzeja Gaczoła

Fragmenty pamiętnika Franciszka Widomskiego

\section{Źródła drukowane}

„Goniec Polowy Legionów. Dziennik Rozporządzeń Komendy Legionów Polskich”, marzec 1915 - maj 1916, nr 1-8, 10, 12-14.

Księga Adresowa Królewskiego Stołecznego Miasta Krakowa i Królewskiego Wolnego Miasta Podgórza 1905. R. 1. Kraków: Nakładem „Spółki Wydawniczej” Józef Knapik i Stefan Mikulski, 1904.

Lista chorych, rannych, zabitych i zaginionych Legionistów do kwietnia 1915 roku. Oświęcim: Centralny Oddział Ewidencyjno-Werbunkowy Departamentu Wojskowego NKN, 1915.

\section{Druki urzędowe}

Szematyzm Królestwa Galicji i Lodomerii z Wielkim Księstwem Krakowskiem na rok (1886-1914).

\section{Opracowania}

Cisek Janusz, Stepan Kamil: Lista strat Legionów Polskich 1914-1918. Kraków: Księgarnia Akademicka, 2006.

Cisek Janusz, Kozłowska Ewa, Wieczorek Łukasz: Słownik Legionistów Polskich 19141918. T. 1. Zalesie Górne: Stowarzyszenie Przyjaciół Zalesia Górnego, Oficyna Wydawnicza Volumen, 2017.

Czerep Stanisław: II Brygada Legionów Polskich. Warszawa: Wydawnictwo Bellona, 1991.

Gaczoł Andrzej: Tadeusz Bierczyński (1891-1970). Legionista, adwokat, poset na Sejm II RP - represjonowany przez reżim stalinowski. „Sowiniec” 2007, nr 31, s. 51-60.

Gawroński Wojciech: Słownik biograficzny wieliczan. Wieliczka: Muzeum Żup Krakowskich, 2008.

Kossewska Elżbieta: Związek Legionistów Polskich 1922-1939. Warszawa: Oficyna Wydawnicza ASPRA-JR, 2003.

Malinowski Tadeusz, Szumański Mieczysław: 2. Pułk Piechoty Legionów Polskich. I Karpaty. Kronika działań bojowych. Warszawa: Koło 2. Pułku Piechoty Legionów Polskich, 1939. 
Milewska Wacława, Nowak Janusz Tadeusz, Zientara Maria: Legiony Polskie 1914-1918. Zarys historii militarnej i politycznej. Kraków: Księgarnia Akademicka, 1998.

Nie tylko Pierwsza Brygada. Z legionami na bój. Cz. 1. Oprac. Stanisław Jan Rostworowski. Warszawa: P. W. Egross, 1993.

O miłości Ojczyzny nie deklamowaliśmy... Wspomnienia Antoniego Sejmeja Górszczyka. Oprac. Sylwester Rękas. Warszawa: Naczelna Dyrekcja Archiwów Państwowych, Archiwum Narodowe w Krakowie, 2019.

Porwit Marian: Spojrzenia poprzez moje życie. Warszawa: Czytelnik, 1986.

Sitko Józef: Zarys historii wojennej 2-go Pułku Piechoty Legionów. Warszawa: Wojskowe Biuro Historyczne, 1928.

Spis bytych żotnierzy Legionów Polskich opracowany w 1973 r. przez mgr. inż. Władysława Rzepeckiego oraz płk. dypl. Władysława Jamke. W: Jadwiga Duda, 131 spotkanie z cyklu ,,Wieliczka-Wieliczanie”. W 90. Rocznicę odzyskania przez Polskę Niepodległości (1918-2008). Udział Wieliczan w walce o Niepodległość. Biblioteczka Wielicka z. 76. Wieliczka: Powiatowa i Miejska Biblioteka Publiczna w Wieliczce, 2008, s. 30-39.

Śmieszne to życie! Ale go żal... Dzienniki Kazimierza Filara. Cz. 1-2. Oprac. Piotr Szlanta. Warszawa: Naczelna Dyrekcja Archiwów Państwowych, Archiwum Narodowe w Krakowie, 2018.

Taczanowski Kazimierz: Podpułkownik Jan Stuszkiewicz. „Wiadomości Bocheńskie” 2018, R. 30, nr 4 (118), s. 14-15.

Wroński Tomasz: Udział mieszkańców Bieżanowa w walce o niepodległość Polski (19141920). Kraków: Archiwum Narodowe w Krakowie, 2019.

\section{Wydawnictwa elektroniczne}

Kartoteka personalno-odznaczeniowa (baza danych Wojskowego Biura Historycznego im. gen. broni Kazimierza Sosnkowskiego), https://wbh.wp.mil.pl/pl (odczyt: 02.03.2020).

Lista odznaczonych Krzyżem i Medalem Niepodległości (baza danych Instytutu Pamięci Narodowej), https://niezwyciezeni1918-2018.pl (odczyt: 02.03.2020).

Strona internetowa Towarzystwa Przyjaciół Grodna i Wilna Oddział we Wrocławiu, http:// grodnowilno.pl/gajczewska-ludmila (odczyt: 02.03.2020).

Żołnierze Niepodległości (baza danych Muzeum Józefa Piłsudskiego w Sulejówku), https:// muzeumpilsudski.pl (odczyt: 02.03.2020).

AUTORZY: Kamila Follprecht - historyk archiwista, dr, Archiwum Narodowe w Krakowie; zainteresowania badawcze: właściciele i mieszkańcy krakowskich nieruchomości od XVI do XX w., edytorstwo źródeł historycznych; e-mail: kfollprecht@ank.gov.pl

Andrzej Gaczol - inżynier architekt, dr hab., emerytowany profesor Politechniki Krakowskiej, Wydział Architektury - Katedra Historii Architektury i Konserwacji Zabytków, Wojewódzki Konserwator Zabytków w Krakowie 1993-2003, konserwator zabytkowych budynków Uniwersytetu Jagiellońskiego 2003-2014; zainteresowania badawcze: historia architektury i urbanistyki, szczególnie dzieje konserwatorstwa oraz biografistyka; e-mail: a.gaczol@wp.pl 
AUTHORS: Kamila Follprecht - historian, archivist, Dr, National Archives in Krakow; research interests: owners and residents of Krakow's properties from the $16^{\text {th }}$ century until the 20 $0^{\text {th }}$ century, editing of historical sources; e-mail: kfollprecht@ank.gov.pl

Andrzej Gaczol - engineer, architect, Dr hab., retired professor of Cracow University of Technology, Faculty of Architecture - Department of Architectural History and Monument Conservation, Voivodship Conservator of Monuments in Krakow 1993-2003, conservator of Jagiellonian University's buildings 2003-2014; research interests: history of architecture and urban planning, especially events concerning conservation, as well as biographies; e-mail: a.gaczol@wp.pl 